\title{
Institutional Investors' Ownership Stability and Firms' Innovation
}

\author{
Hamid Sakaki ${ }^{1}$
}

Surendranath R. Jory ${ }^{2}$

\begin{abstract}
We examine the relationship between various measures of institutional ownership and investee firms' level of innovation as measured by the number of patents and patent citations. We find a direct association between the stability in the equity ownership of institutional investors and their investee firms' level of innovation. Our main finding would serve to reassure managers that they benefit from the support of long-term-oriented institutional investors who adopt a "buy and hold" investment philosophy as opposed to a "trading" philosophy. We also examine the association between the proportion of a firm's equity held by institutional investors and its innovation and find that it relies on the type of the investor. For instance, while there exists a positive association between mutual funds and firm innovation yet, the association is only positive for funds that actively manage their portfolios different from their benchmark index. Next, pressure-sensitive institutional investors' shareholdings are positively correlated with firm innovation; however, it is not necessarily the case for all the pressure-insensitive investors.
\end{abstract}

JEL Classification: O31, G32, G34

Keywords: Institutional investors, Firms' innovation, Patents, Citations

\footnotetext{
${ }^{1}$ Department of Finance, Central Connecticut State University, New Britain, CT, USA. Phone: (860) 832-2378, Email: hamid.sakaki@ccsu.edu.

${ }^{2}$ University of Southampton, Highfield, Southampton, SO17 1BJ, United Kingdom. Email: S.R.Jory@soton.ac.uk; Tel: +44(0)238059 5923; Fax +44 (0)23 80593844

We would like to thank the Associate Editor, Claire Crutchley Lending, and two anonymous reviewers for their comments and suggestions.
} 


\section{Introduction}

Institutional investors have amassed considerable stock ownership over time. Tonello and Rabimov (2010) document that these investors have doubled their shareholdings from $28.4 \%$ in 1980 to $53.5 \%$ by 2005 . Blume and Keim (2012) document an increase from between 7 and $8 \%$ in 1950 to $67 \%$ by 2010 . Based on these statistics, institutional investors own two out of every three U.S. stocks outstanding. As a result, they constitute an important group of investors in the U.S. Simultaneously, U.S. corporations are investing heavily in innovations, research and development and related activities in pursuit of growth. Kota, Talbot-Zorn and Mahoney (2018) exhort the significance of innovation to the U.S., i.e., that the nation needs both research and development (R\&D) and manufacturing activities to maintain a healthy 21 st Century industrial ecosystem.

It is therefore vital to study institutional investors' role in supporting innovations at U.S. corporations given their importance in providing equity funding to these firms. The significant influence of institutional investors on other corporate decisions (i.e., excluding innovations) is well documented (e.g., McConnell and Servaes 1990; Smith 1996; Carleton et al. 1998; Gillan and Starks 2000; Hartzell and Starks 2003 and Boehmer and Kelley 2009). Not only do institutional investors attempt to influence corporate policies, but their presence serves to improve stock market efficiency (Boehmer and Kelley, 2009); to reduce agency conflicts and force managers to create more wealth for shareholders (Cornett et al., 2007). Institutional investors use a variety of measures to align managers' and shareholders' interests including securities litigation (Chen et al., 2010), and “just vote no" campaigns (Guercio et al., 2008). This paper examines the extent to which institutional ownership and the stability in the ownership over time are associated with innovation (which is another vital corporate decision in terms of 
the investment that it requires to maintain a firms' competitive edge in the market) at their investee firms. Innovation assists companies to stay competitive, to grow, to serve new markets, among others, which helps to generate wealth for investors. Innovation is a simultaneously risky undertaking, in the sense that its commercial success is not guaranteed. Indeed, there are more innovation failures than successes. Besides, innovation is a costly undertaking, and if its success cannot be assured, then it ends up costing shareholders dearly. How supportive are institutional investors of firms' innovations? This support is essential to reassure managers that institutional investors would back their innovation efforts. The purpose of the current study is to document institutional investors' patronage of innovative firms.

By investors' support, we mean not only the proportion of shares of innovative firms held by investors but also the stability in those shareholdings. Documenting the stability is important since many institutional investors (who tend to hold large shareholdings) very often do not have the choice to look beyond short-term gains (see Kochhar and David, 1996). Like firm managers, a high number of fund managers are under pressure to generate wealth for their sponsors (Graves and Waddock, 1990), and, therefore, these funds, in particular, are less likely to hold the shares of innovative firms that cannot profitably exploit their innovations in the short run. Innovation is often a long-term process with commercial exploitation and financial success achievable only in the long term or not at all. Do these firms, therefore, suffer from a lack of support from certain institutional investors? To the extent that a significant group of institutional investors evaluates firms based on financial rather than innovation measures, then a broad cross-section of managers would be reluctant to engage in high-risk costly innovation activities to avoid the adverse consequences of those institutional investors shunning their firms. Thus, there are real economic consequences of institutional investors' shareholdings of innovative firms. 
Nonetheless, it would be rash to assume that all kinds of institutional investors are under short-term pressure to avoid the stocks of innovative firms. One of the areas where innovation is humming, for example, is among start-up firms, and the role of major institutional investors in providing seed funding (which cannot be easily divested) is well documented (see Hall and Lerner (2010)) despite the high failure rate among start-ups. Some institutional investors spend a great deal of time and effort in identifying the next big idea that is worth pursuing, and it is through this process of diligence that they expect to create more wealth for their financial sponsors and investors. In so doing, there is a high likelihood that these institutional investors would support firms that pursue innovations that could potentially be an enormous hit both commercially and financially. It becomes therefore imperative to differentiate among the types of institutional investors in the study of innovation. Investors that are under pressure to avoid the risks associated with innovation would not necessarily support these firms. Conversely, these firms would potentially benefit from the financial backing of institutional investors that are chasing long-term value.

To measure innovation at corporations, we use the following proxies: (i) the number of patents filed, and (ii) the number of non-self-citations, obtained from the National Bureau of Economic Research (NBER). These two measures are commonly used to proxy for a firm's innovation initiatives (for instance, Griliches et al., 1988; Lerner et al., 2011; Seru, 2014; Fang et al., 2014; and Cornaggia et al., 2015). In contrast to studies that measure firm innovation using research and development $(\mathrm{R} \& \mathrm{D})$ expenditure, patent count and citation count —as measures of innovation—do not only allow us to assess a firm's willingness to undertake innovation activities (which R\&D expenditure does) but also enable us to measure the success of those efforts (which R\&D expenditure does not necessarily achieve). We test whether institutional ownership is 
positively related to innovation since it constitutes a source of growth and wealth for corporations and their investors (Solow, 1957; Porter, 1991), and we find a positive association between them. It implies that firms need not agonize about whether institutional investors would back their R\&D efforts since we establish that the association between institutional ownership and firm innovation is positive. However, since we measure innovation using patent and citation counts, our results also suggest that institutional investors' ownership is positively related to firms that file more patent counts and that garner more citation counts. Thus, to benefit from the backing of institutional investors, innovative firms would also focus on these two measures and maximize the likelihood of exploiting their innovations profitably.

The prime focus of the paper though is to examine how the persistence or stability in the equity ownership of institutional investors relates to investee firms' innovations. We argue that stability in the ownership of shareholdings would afford the investee firm the time and resources needed to try different innovations. Conversely, a high turnover in the ownership of institutional investors does not provide the investee firm with an environment conducive to pursue innovation. Indeed, we find our measures of firm innovation to be directly related to the stability of institutional shareholdings.

In our attempt to further analyze the association between firm innovation and the proportion of their shares held by institutional investors, we note that there exists a great heterogeneity among the investors, especially among mutual funds. Some mutual funds actively manage their equity portfolios irrespective of their benchmark index (i.e., active investors), while others tend to mirror the shareholdings of their benchmark index (i.e., passive investors). We differentiate between active mutual funds (i.e., stock pickers, concentrated) and passive ones (i.e., closet indexers) using Cremers and Petajisto (2009) and Petajisto (2013) measures of active 
share and tracking error, and test whether their association with a firm's R\&D efforts differ. ${ }^{3}$ In between the two extremes (i.e., active versus passive), there are middle-of-the-road mutual funds, i.e., factor bets and moderately active funds. ${ }^{4}$

We find a positive association between the measures of innovation (i.e., patent count and citation count, respectively), and each of the proportions of shares held by stock pickers and concentrated institutional investors (i.e., the active mutual funds). Conversely, the association between innovation and the equity ownership of the middle-of-the-road mutual funds (i.e., factor bets, and moderately active mutual funds) is negative. These funds are neither entirely active nor entirely passive. Thus, their portfolio choices are confounded by, on the one hand, some degree of freedom in selecting stocks and, on the other hand, by the constraints imposed through the stock composition of their benchmark index. As a result, there is no clear-cut basis to explain the inverse association between their shareholdings and their portfolio firms' measures of innovation. We also find that there is no association between closet indexers' equity ownership (i.e., passive mutual funds) and either of patent count or citation count, which is to be expected since closet indexers do not form their investment portfolios based on the outcomes of firms' innovation efforts.

The findings suggest that institutional investors with a mandate to pick stocks differently from the stock composition of their benchmark indices (i.e., active stock pickers) are knowingly investing in the shares of innovative firms. It should serve to reassure managers that in pursuing innovation, they would benefit from the support of actively-managed mutual funds. The finding

\footnotetext{
${ }^{3}$ Schumacher (2016) explains the differences between the different types of mutual funds at: http://www.morningstar.co.uk/uk/news/147726/how-to-measure-a-funds-level-of-active-management.aspx/ ${ }^{4}$ See Marte (2011). The New Case for Balanced Funds. The Wall Street Journal, May 13. Accessed at: https://www.wsj.com/articles/SB70001424052748703730804576319190569959786
} 
of no relationship between the shareholdings of closet indexers and our proxies of innovation is explained by the fact that these investors tend to mirror the stock composition of their benchmark stock index. Therefore, their basis of stock selection is wholly dictated by other factors than the number of patents filed by the portfolio firms.

The degree of heterogeneity among institutional investors further suggests that should their investment motives differ, then their attitude to innovative corporations would vary as well. The database used for the present study allows us to differentiate between pressure-sensitive (i.e., banks and insurance companies) and pressure-insensitive (i.e., mutual funds/investment companies and investment advisers) institutional investors. The number of patent and citation counts are both positively associated with the proportion of shares held by banks, insurance, and mutual funds/investment companies, respectively; however, both innovation measures are negatively related to the share ownership of investment advisors.

Banks and insurance companies tend to be pressure-sensitive investors. In other words, besides their stock ownership, they tend to have other business ties with their portfolio firms and to preserve those ties these investors tend not to confront management. Since we find that the stock portfolios of these pressure-sensitive investors are associated with firms that innovate successfully, we argue that this finding points to the support that innovative firms benefit from their institutional backers and investors.

Unlike banks and insurance companies though, mutual funds and investment advisers do not have to concur with portfolio firms' management on every decision since, besides their equity stake in those portfolio firms, they have no other business ties to preserve. We find that the stock portfolios of mutual funds are positively associated with both the number of patent counts and 
number of citation counts of portfolio firms. However, in the preceding paragraphs, we discussed the different types of funds (i.e., active versus passive) and deliberated the finding that the positive association is mainly due to active mutual funds (i.e., stock pickers and concentrated mutual funds). Conversely, there exists a weak but negative association between investment advisors' shareholdings and the innovation measures of those shares. Note though that the demands of their clients entirely dictate investment advisors' investment behavior. Such client demands may or may not include the number of patents filed and the number of citations counts as investment criteria.

We make several significant contributions to the literature. First, we contribute to the burgeoning literature that examines the link between institutional ownership and firm innovation, which includes studies like Aghion, Reenen, and Zingales (2013). These studies show that there exists a positive association between institutional ownership and firm innovation (similar to our findings but using alternative measures of innovation). We add to the literature by documenting that there also exists a positive association between the stability in the institutional ownership and firm innovation. In other words, firms' innovation efforts that result in successful patent counts and a high number of citations are associated with a lower standard deviation in the shareholdings of their institutional investors. To the best of our knowledge, ours is the first study to document this link. Second, our results conjure up that in studies of innovation, institutional investors (which include a variety of investors, i.e., banks, insurance, investment advisors as well as a diversity of mutual funds) cannot be treated as a homogenous group since the heterogeneity among this diverse group (i.e., in terms of investment motives, behavior, horizons, among others) affects their ownership of firms that actively pursue innovation. This study documents the various relationships using two systematic taxonomies of institutional investors (i.e., using 
Cremers and Petajisto, 2009, and Petajisto, 2013 classification, and the Thomson Reuters' classification, respectively).

The rest of the paper proceeds as follows. Section 2 consists of a literature review and the development of hypotheses. Data sources, sample construction and methods used are explained in Section 3. Results are presented and explained in Section 4. The final section concludes the paper.

\section{Literature Review and Hypothesis Development}

There are a few studies that examine the association between financial metrics and firms' innovations. For instance, He and Tian (2013) find that analysts' coverage tends to adversely affect firms' innovations since analysts' focus is too short term. Similarly, stock liquidity adversely affects firms' innovations according to Gang et al. (2014). There are even fewer studies that examine institutional investors and firms' innovations. However, the relatively small existing literature in this area suggests that institutional investors have a positive impact on firms' innovation. Francis and Smith (1995), and Eng and Shackell (2001) show a positive association between institutional ownership concentration and R\&D expenditure. Bushee (1998) shows that firms with higher institutional ownership are less likely to cut R\&D expenses.

Recently, Aghion et al. (2013) examine the relationship between institutional investors and firms' innovation. They present two hypotheses: the lazy manager hypothesis and manager's career risks hypothesis. The lazy manager's hypothesis postulates that managers who prefer a quiet life or desire to maintain the status quo would not invest in innovations; however, pressures from institutional investors would force them to innovate. Under the manager's career risk hypothesis, managers are apprehensive about the consequences of failed R\&D activities (for 
instance, their employment could be terminated); however, such an approach would not benefit institutional investors. The authors find that institutional investors increase innovation by reducing managers' career risk. Taken together, the literature suggests a supportive role played by institutional investors vis-à-vis firms' research and development efforts.

We propose to take the analysis between institutional ownership and firm innovation one step further by examining the volatility in the shareholdings of institutional investors on the actual productivity of the innovation process and focus on the number of patent applications a firm is granted and the number of non-self-citations the patent garners subsequently. Engaging in research and development and innovations is fraught with risk and costs a lot of money, and many such efforts fail. To reassure managers and to make them more willing to undertake $R \& D$ and innovation, we posit that the presence of stable institutional investors is indispensable. A lack of stability in the shareholdings of institutional investors would send mixed signals to the firm managers as to the real motivations of the investors for holding the firm shares. Given the high risk of a failed innovation (in terms of cost, the firm's competitive position, and both the reputational and career risks that a manager would endure), it is hard to presume that managers will be assured in engaging in risky ventures if institutional investors are fixated on the shortterm and they are trading their positions actively. Short-term investors who desire a quick profit would not view activities with a high failure rate favorably. Managers indeed decry the presence of short-term investors as evidenced by the survey of Bailey and Godsall (2013), who report: 
"86\% declared that using a longer time horizon to make business decisions would positively affect corporate performance in a number of ways, including strengthening financial returns and increasing innovation."

The Institutional Investor (2016) notes a substantial increase at which individual stocks are changing hands over time (pointing to volatility in institutional shareholdings), which it argues represents a "trading" rather than a "buy-and-hold" investment philosophy adopted by many U.S. institutional investors. ${ }^{6}$ This shift in investment approach aided by information technology, high-frequency trading, news channels, among others, is exerting tremendous pressure on managers to deliver short-term targets at the expense of longer-term ones. By examining the volatility in institutional ownership, we are able to test the hypothesis that stability in the ownership of institutional investors significantly affects a firm's ability to innovate. Thus, our central hypothesis examines whether the volatility in the proportion of shares held by institutional investors is directly related to (i) the number of patents filed by investee firms, and (ii) the number of times others cite the patents.

The counter-hypothesis is that while it is plausible to assume that innovation requires the support of stable investors, yet innovation is an inherently risky undertaking and if institutional investors prefer stability in their shareholdings, then there is no pressure for firms to innovate since the pursuit of stability in ownership would not lead the investors to divest their

\footnotetext{
${ }^{5}$ Source: Institutional Investor (2016). Long-Termism Versus Short-Termism: Time for the Pendulum to Shift? Retrieved from https://www.institutionalinvestor.com/article/b14z9mxp09dnn5/long-termism-versus-shorttermism-time-for-the-pendulum-to-shift

${ }^{6}$ Ibid.
} 
shareholdings even if the firm fails to innovate. To minimize risk, these firms may forego innovations that are risky and uncertain.

A number of the aforementioned studies on the association between institutional investors and firms' innovations tend to treat institutional investors as a homogeneous group. However, there is a great heterogeneity among these firms (Brickley et al., 1988; Almazan et al., 2005; Chen et al., 2007). For instance, Brickley et al. (1988) find that the investment motives of pressure-insensitive investors differ from pressure-sensitive ones. Using the Bushee (1998) classification, Aghion et al. (2013) observe that quasi-indexed institutions have no association with innovation, while other types of institutional owners have a positive association with innovation. To account for the heterogeneity that exists amongst institutional investors, we adopt a multipronged approach.

First, we differentiate between (i) institutional investors that manage their portfolios differently from stock market indices (i.e., active investors) from (ii) investors that track market indices (i.e., passive investors or indexers). It is reasonable to expect that indexers would bear little direct influence on a firm's innovation undertakings since their investment decisions are based on whether the firm is a component (or not) of the index their equity portfolios track. Conversely, active investors over- or under weigh stocks in their portfolios relative to their benchmark index based on a number of factors. To the extent that innovation drives economic growth, which is highly dependent on growth in the corporate sector that in turn drives corporate profitability, it is plausible to assume that investors who actively manage their equity portfolios differently from their benchmark index would also analyze the lucrativeness of firms engaged in innovations. Thus, we test the hypothesis that the shareholdings of active institutional investors are directly related to the number of patents filed by a firm as well as the number of citations of 
the patents by others. These two measures of innovation provide a sense of the actual productivity of the innovation process and are essential determinants in innovations that are the road map to corporate riches.

Geroski and Machin (1993) document that innovations have a positive effect on profitability and growth. Sayili, Yilmaz, Dyer, and Küllü (2017) find that growth-oriented institutional investors enhance firm innovation. Thus, there exists a cluster of institutional investors who seek innovative firms. We argue that such investors (i.e., active investors) should have the option to select stocks differently from their benchmark indices (which passive investors do not possess) to be able to target innovative firms. Thus, if we were to differentiate between active and passive investors, we are less likely to find an association between passive investors' shareholdings and firm innovation since these investors exercise no discretion in their stock selection. Should there be a link between institutional ownership and firm innovation, it should come from the active investors' subcategory.

This classification of institutional investors based on the degree to which they actively manage their portfolios has been used in studies of innovation (for example, Aghion et al. (2013)). Following Bushee (1998), Aghion et al. (2013) differentiate between dedicated, transient and quasi-indexers. Dedicated institutional investors adopt a long-term investment horizon (characterized by the low turnover in their stock portfolios) and hold large portions of the equity of their investee firms. Conversely, transient investors trade frequently, and the composition of their portfolios is the least constant. As their name suggests, quasi-indexers' equity portfolios exhibit diversified holdings and low portfolio turnovers. Aghion et al. (2013) find that quasi-indexed institutions have no association with innovation, while other types of 
institutional owners have a positive association with innovation. A similar classification is used in the study by Fang et al. (2014).

Since we study the extent to which an institutional investor actively departs from the shareholdings of benchmark stock market indices, we follow the approach of Cremers and Petajisto (2009) given that our dataset contains mutual funds as a subgroup of institutional investors. ${ }^{7}$ Their classification system also allows us to refine further the extent to which investors actively manage their equity portfolios by regrouping them into various subgroups.

Cremers and Petajisto (2009) develop Active Share (AS) to represent the share of portfolio holdings that differ from benchmark index holdings. The added benefit of using (AS) is that it can be combined with tracking error for a more comprehensive picture of active management. Besides Cremers and Petajisto (2009) classification of funds, we classify institutional investors among the following: (i) banks, (ii) insurance companies, (iii) mutual funds/investment companies, and (iv) others. This classification is particularly important for our purposes since it allows us to test how banks' ownership affect firms' innovations. Given their expertise in assessing corporations (since they are the primary lenders to the corporate sector), we are able to test the degree to which they support (or not) firms' innovations by examining their equity ownership level at these firms.

The examination of the shareholdings of insurance companies is also crucial. Insurance companies are adept at identifying and managing risks. Innovations, on the other hand, comprise of experimental methods with a high probability of failure (Holmstorm, 1989). Do insurance companies assist in differentiating between less- and more risky innovations? The process of

\footnotetext{
${ }^{7}$ We use the terms mutual funds and investment companies interchangeably.
} 
assessing risk by insurance companies can benefit the corporate sector. We test the hypothesis that the shareholdings of insurance companies are directly related to firms' innovation and R\&D projects.

\section{Data and Sample Selection}

\subsection{Data}

The data for this study is compiled from several sources. First, institutional owners' data is collected from the Thomson Reuters' database. Second, we obtain the active share data which are available from 1980 to 2009 from Professor Petajisto's website ${ }^{8}$ (Petajisto, 2013). Third, we obtain innovation data from the latest version of National Bureau of Economic Research (NBER) initially created by Hall et al. (2001) ${ }^{9}$. This database covers $3,032,482$ patents granted in six different categories by the United States Patent and Trademark Office (USPTO) between 1976 and 2006. The NBER database includes information on: an identifier of Compustat records (GVKEY), the number of patents, a patent's application year, a patent's grant year, the number of citations received by each patent (ALL_CITES), and unique assignee number (PDPASS). Based on the NBER patent data definition, a patent assignee can be either an individual or a corporation, who is recognized as the patent owner. Accounting and financial information are collected from the annual Compustat database and trading volume data are collected from the University of Chicago's CRSP database.

We match each assignee number (PDPASS) with a Compustat identifier (GVKEY) provided by NBER. We then merge information obtained from the NBER database with Thomson Reuters' database and active share data. Since the NBER database only covers patent

\footnotetext{
${ }^{8} \mathrm{http://www.petajisto.net/data.html}$.

${ }_{9}^{9}$ Data are available at https://sites.google.com/site/patentdataproject/Home/downloads.
} 
information up to 2006, we exclude the last two years of the sample because of truncation problems. We also exclude financial and utility firms (i.e., SIC codes 6000-6999 and 4900-4999) due to their regulated status. The final sample covers the period $1981-2004$, includes 61,225 firm-year observations covering 10,062 different firms as shown in Panel A Table 1. Panel B presents the sample distribution by industry based on the Fama and French 12-sector industry classification. The Business equipment category has the largest share of the final sample (22.14 $\%$ ), while Telephone and Television Transmission is the industry with the least number of observations (2.73\%).

\section{[INSERT TABLE 1 ABOUT HERE]}

\section{Methodology}

\subsection{Measures of Institutional Investors}

To measure institutional ownership stability, we follow Elyasiani et al. $(2008,2010)$ and use institutional ownership volatility of firm $i\left(I O V_{i}\right)$, which is the average standard deviation of institutional shareholding proportions across all investors $j$ in firm $i$ over a five-year period including the sample year and the four years preceding (i.e., 20 quarters). ${ }^{10}$

$I O V_{i}=\Sigma_{j=1}^{j_{i}} \operatorname{Std}\left(p_{i, t}^{j}\right) / J_{i}$

where $p_{i, t}^{j}$ is the proportion of firm $i$ held by investor $j$ in quarter $\mathrm{t}(\mathrm{t}=1,2, \ldots, 20)$, and $j_{i}$ is the number of institutional owners in firm $i$. The higher the ownership volatility, the lower is the institutional ownership stability and vice versa.

${ }^{10}$ Also used in Jafarinejad et al. (2015), Jory et al. (2017) and Sakaki et al. (2017) 
To control for the effect of institutional ownership level on firms' innovation, we also consider the aggregate ownership proportion (Elyasiani et al., 2010). The aggregate ownership proportion of a firm is computed over a five-year period as:

$\operatorname{PROP}_{i}=\left(\Sigma_{t=1}^{20} \Sigma_{j=1}^{j_{i}} p_{i, t}^{j}\right) / 20$

We apply Cremers and Petajisto (2009) measures of Active Share and Tracking Error to differentiate between active and passive institutional investors' subgroup of mutual funds. Active Share is computed as follows:

$$
\text { Active Share }=\frac{1}{2}{ }_{i=1}^{N} \sum\left|W_{\text {fund }, i}-W_{\text {index }, i}\right|
$$

where $W_{\text {fund,i }}$ and $W_{\text {index,i }}$ are the portfolio weights of asset $i$ in the fund and in the index respectively, and the sum is taken over the universe of all assets. Active Share indicates what percentage of a fund's portfolio overlaps with its benchmark index. For example, if Active Share equals $80 \%$, it suggests that only $20 \%$ of the fund's portfolio overlaps with the benchmark index. Tracking error represents the standard deviation of the differences between the fund's portfolio return and its benchmark index return over time (Grinold, 1999).

Tracking error $=\operatorname{Stdev}\left[r_{f, t}-r_{i, t}\right]$

where $r_{f, t}$ is the fund return and $r_{i, t}$ is the benchmark index return. Following Petajisto (2013), by using these two variables, we create the cutoff to define different types of active management. Following Petjisto's classification, the most active mutual funds are stock pickers and the most passive mutual funds are closet indexers. In between the two and moving from active to passive, we find the following categories: concentrated (more active), factor bets and moderately active (more passive). 


\subsection{Measures of Innovation}

Following the literature (Lerner et al., 2011; Seru, 2014; Fang et al., 2014, and Cornaggia et al., 2015), we use a firm's patenting activity to capture the firm's innovation by considering the number of patent applications a firm files (PC) in a year that are eventually granted and the number of non-self-citations each patent receives in subsequent years (CC) accessed from the NBER database. We use the patent's application year instead of the patent's grant year because the application year more closely reflects innovation timing (Griliches et al., 1988) as there is often a considerable lag between patent application and granting.

Usage of NBER patent data creates two truncation problems. Since the patents appear in the NBER database only after they are granted, the first truncation problem arises. Being more specific, the number of patents decreases gradually as we reach the last years of the sample period because there is an average of two years' lag between application and grant years. Therefore, patents applied for but have not yet been granted by the end of 2006 (the last year of the database) would not feature in the NBER database. The second truncation problem is associated with the number of citations. Each patent is continually cited over the period, and as we move toward the end of the NBER database sample period, the number of citations for the recently granted patents decreases. For example, a patent issued in 1998 is expected to receive more citations compared to a patent obtained in 2004, all things being equal. To overcome the truncation problem, we use the truncation correction weights calculated from citation lag distribution following Hall et al. (2001, 2005). Given that the truncation problems are more severe toward the end of the sample period, we exclude the last two years of the database (i.e., 2005 and 2006) from the analysis. 
Many institutional investors are not privy to proprietary information about a firm's innovations and therefore rely on publicly available information like patent and citation counts. Indeed our research documents a significant association between their stock ownership and these two variables.

Past studies (for example, Jarrell et al. (1985)) examine firms' R\&D expenditure assuming that innovation is associated with higher $R \& D$ expenditure. We control for $R \& D$ expenditure in the multiple regressions. The issue with using $R \& D$ expenditure as a proxy for innovation is that while it measures the firm's willingness to spend on R\&D, it does not say much about the success of the innovation outcomes. Take the example of two firms with the same expenditure budget, yet one files more cited patents while the other one is unable to do so. Using R\&D expenditure alone would suggest that both firms are equally innovative. Yet, the second firm is not as successful in its innovation efforts as the other firm.

Conversely, using patent counts and citation counts allow us to measure the success of the R\&D efforts. We surmise that a firm with less $R \& D$ expenditure but a higher number of patent and citation counts is more innovative than a similar firm with less patent and citation counts. Another issue with using R\&D intensity as a measure of innovation is that it does not capture the outcome of the R\&D; while patent counts and citation counts, in particular, help to assess the result of the innovation efforts and expenditure partially. Nonetheless, patents represent a means of protecting the intellectual property developed by a firm, and other innovations may not be patented by firms (trade secrets), or that cannot be patented (tacit knowledge). 
Using patent counts as a measure of innovation has advantages and disadvantages as discussed in Trajtenberg (1990). For instance, a simple patent count assigns a value of one to all patents but does little to recognize their real economic benefit to the firm. To compensate for the shortcomings of patent counts, Trajtenberg (1990) advocates the simultaneous usage of citation counts, i.e., the number of times a patent is referenced in subsequent patent applications, in studies measuring firm innovations. The number of citation counts is directly associated with the commercial significance of the referenced patent given that they tend to be referenced by profitseeking agents for most of the time

\subsection{Institutional Investors and Firms' Innovation Regression}

To test for the effect of institutional ownership on innovation, we run the following regression model, which accounts for other firm-specific characteristics that may influence innovation:

$$
\begin{aligned}
& P C_{i, t+n}\left(C C_{i, t+n}\right)=\alpha_{0}+\beta_{1} I O V_{i, t}+\beta_{2} P R O P_{i, t}+P C_{t-1}+C C_{t-1}+\beta_{3} L N_{-} S A L E_{i, t}+\beta_{4} R D T A_{i, t}+ \\
& \beta_{5} R_{0 A} A_{i, t}+\beta_{6} \text { PPETA }_{i, t}+\beta_{7} L E V_{i, t}+\beta_{8} \operatorname{CAPEXTA}_{i, t}+\beta_{9} Q_{i, t}+\beta_{10} H_{H} I_{i, t}+\beta_{11} H_{H I}^{2}{ }_{i, t}+ \\
& \beta_{12} L N \_A G E_{i, t}+Y E A R_{t}+\operatorname{INDUSTR} Y_{i}+\varepsilon_{i, t}
\end{aligned}
$$

where $i$ and $t$ indicate firm and time respectively, and $n$ equals 1,2 , or 3 . As the innovation process is time consuming, we consider the impact of institutional ownership on patenting activities up to $t+3$ years. The consideration of three different leads of the dependent variables (i.e., $\mathrm{PC}$ and $\mathrm{CC}$ ) helps to control for the reverse causality. $P C$ is the natural logarithm of one plus a number of patents filed and eventually granted, and $C C$ is the natural logarithm of one 
plus a number of non-self-citations per patent. ${ }^{11} \mathrm{IOV}$ is calculated as the average standard deviation of shareholding proportion across all the institutional investors over a five-year period.

The control variables are as follows: institutional ownership proportion $\left(P R O P_{t}\right)$, which is the average aggregate institutional shareholding proportion across the five-year period; firm size $\left(L N_{-} S A L E_{t}\right)$. A measure of the firm's existing stock of patents $\left(P C_{t-1}\right)$ is included in the model. This is critical because filing for licenses with the patent office requires resources and know-how. If a firm has filed for patents in the past, it has this know-how and it is easier to continue to register new copyrights. So the existing licenses that a firm has are an essential determinant of the future patents it files. Following Sheikh (2012) firm size is measured as the natural logarithm of total sales; research and development expenditures $\left(R D T A_{t}\right)$, which is the ratio of research and development expenditure (set to zero if missing) ${ }^{12}$ to total assets; profitability $\left(R O A_{t}\right)$ measured as operating income before depreciation divided by total assets; Asset tangibility $\left(P P E T A_{t}\right)$ which is measured as the ratio of property, plant, and equipment to total assets; Leverage $\left(L E V_{t}\right)$ measured as book value of debt (sum of long-term debt and debt in current liabilities) divided by total assets; investment in fixed assets $\left(C A P E X T A_{t}\right)$ measured as capital expenditures scaled by total assets; Growth opportunities $\left(Q_{t}\right)^{13}$, which is defined as Tobin's Q; product market competition $\left(H H I_{t}\right)^{14}$ measured by the Herfindahl index based on annual sales and the square of $H H I\left(H H I^{2}{ }_{t}\right)$ to mitigate the nonlinear impact of product market

\footnotetext{
${ }^{11}$ In this study, firm-year observations with zero patents represent $70 \%$ of our sample and it is comparable to the 73\% and 77\% reported in Tian and Wang, 2014 and Fang et al., 2014, respectively. Therefore, our sample is rightskewed and we remedy this shortcoming by using the logarithm of the adjusted numbers of patents and citations. To avoid losing firm-year observations with zero values we add one to the innovation variables and then take their logarithm.

${ }^{12}$ Following Cornaggia et al. (2015) and Cho et al. (2016), setting the missing variable to zero does not affect the overall results.

${ }^{13}$ Calculated as market value of equity plus book value of assets minus book value of equity minus balance sheet deferred taxes divided by book value of assets.

${ }^{14}$ Herfindahl index of four-digit SIC industry $j$ to which firm $i$ belongs, measured at the end of year $t$.
} 
competition (Aghion et al., 2005); firm age ( $\left.L N_{-} A G E_{t}\right)$, which is measured by the natural logarithm of one plus the number of years the firm is listed on Compustat. All of the control variables are measured at the end of year t. We run ordinary least squares, fixed effects and three-staged least square regressions, alternately.

\section{Results}

\subsection{Descriptive Statistics of Sample and Correlations}

Table 2 provides sample descriptive statistics. Panel A describes the innovation variables, Panel B describes the institutional ownership variables, and Panel C lists the control variables. The mean logarithm of the number of patent and citation are 0.574 and 0.822 , respectively. Panel $\mathrm{B}$ indicates that the average of institutional ownership volatility (IOV) is $0.681 \%$. Panel C indicates that the mean of institutional ownership proportion (PROP) is $16.838 \%$ over the period.

\section{[INSERT TABLE 2 ABOUT HERE]}

Table 3 presents the Pearson correlation of variables. The correlation coefficients between institutional ownership volatility (IOV) and (i) the number of patents (PC) and (ii) the number of non-self-patent citations (CC) are both negative and significant at the 0.10 level. High values of IOV represents low stability in the equity ownership of institutional investors in the firm. Therefore, the lower stability in institutional equity ownership is associated with lower level of innovation at target firms, and vice versa.

The correlation coefficients between institutional ownership proportions (PROP) and (i) the number of patents (PC) and (ii) the number of non-self-patent citations (CC) are both positive and significant at the 0.10 level. High values of PROP represents high proportion of equity ownership of institutional investors in the firm. Therefore, a high proportion of institutional 
equity ownership is associated with a high level of innovation at target firms, and vice versa. The remainder correlation coefficients are of the expected signs; however, none of the coefficients are high enough to suggest multicollinearity.

\section{[INSERT TABLE 3 ABOUT HERE]}

\subsection{Univariate Analysis}

To distinguish the effect of institutional ownership proportion (PROP) from that of ownership volatility (IOV), we disaggregate the sample based on these two variables into a $3 \times 3$ grid presented in Table 4. We compare and contrast the mean values of the innovation variables, i.e., PC (Panel A) and CC (Panel B) between the highest and lowest values of PROP and IOV, respectively. In Panel A of Table 4, the portfolio with the highest $I O V$ has a lower mean value of PC compared to the portfolio with the lowest $I O V$. The t-tests of differences in means are statistically significant at the 0.01 level.

Moving horizontally from left to right, IOV remains constant while PROP increases. As ownership proportion (i.e., PROP) increases, PC increases as well. The portfolio with the highest PROP has a higher mean value of PC compared to the portfolio with the lowest PROP. The ttests of differences in means are statistically significant at the 0.01 level. In Panel B, the tests of differences in means yield similar results in the analysis of the variable CC.

\section{[INSERT TABLE 4 ABOUT HERE]}

In summary, the univariate analyses suggest that there exists a positive association between institutional ownership stability and the number of patents filed $(P C)$ and the number of non-self-patent citations $(C C)$. Furthermore, and consistent with the previous literature, institutional ownership proportion (PROP) is positively associated with both PC and CC. 


\subsection{Institutional Ownership Volatility}

Table 5 reports the OLS regression results. The dependent variable is PC in Panel A and $\mathrm{CC}$ in Panel B. The coefficient of IOV is negative and significant at the 0.01 level in all the regressions. The coefficient of PROP is positive and significant at the 0.01 level in Models 2 and 3 of Panel A, and it is significant at the 0.01 level in Models 4-6 in Panel B. Thus, there exists an inverse association between the innovation variables and the volatility in institutional equity ownership of the firm. Conversely, the higher the proportion of shares held in the firm by institutional investors, the higher the number of patents filed and the number of times the patents are cited (consistent with Aghion et al, 2013).

The coefficients' sign of several control variables is as expected based on the literature. For example, Cockburn and Henderson (1999) identify firm size as one of the determinants of firms' innovation since larger firms have more resources and competencies to innovate. The coefficient of the natural logarithm of sales is positive and significant at the 0.01 level, which is consistent with Cockburn and Henderson (1999). Bhagat and Welch (1995) state that higher leverage leads to lower innovation. Consistent with Bhagat and Welch (1995), we observe an inverse association between leverage and both the number of patents filed and the number of times a patent is cited. The coefficient of LEV is consistently negative in our regressions. We also find the coefficient of the natural logarithm of the firm's age to be positive and statistically significant at the 0.01 level suggesting that older firms file more patents and are associated with a higher number of patent citations. The coefficient of the Q variable is positive and statistically significant at the 0.01 level suggesting that higher valued firms (which is proxied by Tobin's Q) are associated with more innovations.

[INSERT TABLE 5 ABOUT HERE] 
To control for the effect of time-invariant omitted firm characteristics, we run firm fixedeffect regressions and present the results in Table 6. Both coefficients of IOV and PROP retain their signs and they are significant at the 0.01 level.

\section{[INSERT TABLE 6 ABOUT HERE]}

\subsection{Different Types of Institutional Investors}

Thus far, the results suggest that institutional ownership has a positive and significant effect on investee firms' number of patent counts and number of citations. In this section, we examine whether the relationship is dependent on the type of institutional investor. We classify the institutional investors into one of the following: (i) banks, (ii) insurance companies, (iii) mutual funds, (iv) investment advisors, and (v) others based on Thomson Reuters Institutional (13F) Holdings database. ${ }^{15}$ We calculate the PROP of each group of institutional investors and use them as independent variables in Equation (5). We present the findings in Table 7. BANKS, INSURANCE, MUTUAL FUNDS, ADVISORS and OTHERS are calculated as the percentage of firm $i$ 's outstanding shares held by banks, insurance, mutual funds, investment advisors and others, respectively at the end of year $t$.

We find the coefficients of the variables representing ownership by banks, insurance companies and mutual funds to be positive and statistically significant. The coefficient of the variable representing ownership by investment advisors is negative; while there is no association

\footnotetext{
${ }^{15}$ Spectrum classifies institutional investors into 5 groups: Banks (type code $=1$ ), Insurance companies (type code = 2 ), Investment companies (type code $=3$ ), Independent investment advisers (type code $=4$ ), and others (type code = 5 which includes pension funds, endowment funds, most hedge funds, financial arms of corporations, and others). Nonetheless, Spectrum's classifications contain errors, which are corrected by Professor Bushee and are available at http://acct.wharton.upenn.edu/faculty/bushee/Ilclass.html. We use Professor Bushee's classifications.
} 
between the proportion of investee firm's shares held by the OTHERS group and the firm's counts of patents and citations.

\section{[INSERT TABLE 7 ABOUT HERE]}

This finding is not surprising. To the extent that our sample represents a sizeable portion of the population of institutional investors, we would expect some of them not to target firms that are filing a high number of patents. Should all institutional investors focus exclusively on firms filing patents, then there will not be a demand for shares of firms that file little or no patents.

Naturally, this cannot happen because both sets of firms' shares trade on a daily basis suggesting that there is a demand for both sets. Next, it is possible that not all institutional investors share the same expectations on a firm's patent counts. Furthermore, it is possible that a firm's patent filings do not suggest that the firm will be profitable in the future. Last, but not least, institutional investors' motives differ and in the case of investment advisors, they may be trading based on the preferences of their sponsors and clients, who may have investment objectives that do not account for investee firms' patent counts.

To the extent that the above possibilities exist, it is essential to show that we obtain similar findings by decomposing the set of institutional investors differently. To this end, we use Petajisto (2013) classification of institutional investors into stock pickers, concentrated, factor bets, moderately active and closet indexers. Since these data are only available for mutual funds, we can only perform the analysis by this subgroup of institutional investors, and as a result, the sample size declines. We calculate the PROP of each group of funds and use them as independent variables in Equation (5). We present the findings in Table 8. STOCK PICKERS, CONCENTRATED, FACTOR BETS, MODERATELY ACTIVE and CLOSET INDEXERS are 
calculated as the percentage of firm $i$ 's outstanding shares held by stock pickers, concentrated, factor bets, moderately active, and closet indexers respectively at the end of year $t$.

\section{[INSERT TABLE 8 ABOUT HERE]}

Stock pickers and concentrated mutual funds are the most active investors out of the five categories, and their coefficients are positive and statistically significant. Conversely, factor bets and moderately active are middle-of-the-road funds and manage their stock portfolios less actively, and their coefficients are negative and statistically significant. The coefficient representing share ownership by closet indexers is not statistically significant. The results suggest that not all fund investors target firms filing patents in the same way. Interestingly though, active funds' investee companies file more patents than the companies targeted by less active funds. The flexibility in selecting target firms by active fund managers (for example, stock pickers) afford them the possibility to account for investee firm's drive for innovation. Certain institutional investors actively participate in influencing innovations at investee firms. However, our database does not allow us to differentiate between activist and non-activist investors. In this paper, active investors actively buy and sell stocks in their portfolios as opposed to buy and hold the shares of benchmark indices passively. We hypothesize that active investors factor investee firm's innovations in selecting stocks to form part of their portfolios. However, this classification does not preclude activist investors (i.e., those who influence target firm management) from the group of institutional investors who actively manage their stock portfolios.

The association between innovation and the equity ownership of the middle-of-the-road mutual funds (i.e., factor bets, and moderately active mutual funds) is negative. These funds are neither entirely active nor entirely passive. Thus, their portfolio choices are confounded by, on 
the one hand, some degree of freedom in selecting stocks and, on the other hand, by the constraints imposed through the stock composition of their benchmark index. As a result, there is no clear-cut basis to explain the inverse association between their shareholdings and their portfolio firms' measures of innovation. Conversely,

Passive mutual funds (like closet indexers who replicate stock market indexes) do not actively manage their equity portfolios, and therefore an investee firm's patent counts would not figure in their investment decisions. Closet indexers closely track their funds' underlying benchmark index. The most common benchmark indices follow the broad market or specific sectors/industry of the market. Others are based on value or growth stocks. However, benchmark indexes are not based on the innovations of constituent firms, and as a result, there is a lack of association between the shareholdings of closet indexers and the innovation measures of investee firms.

\subsection{Three-stage least squares regression}

To account for potential endogeneity problem, we run a simultaneous-equation regression of innovation and institutional ownership using the technique of three-stage least-squares (3SLS) method. Table 9 reports the results of 3SLS estimations. The coefficients of IOV retain their signs and significance as in the OLS and fixed effects regressions and, therefore, our findings are robust to issues of endogeneity.

\section{[INSERT TABLE 9 ABOUT HERE]}

We do not discount the possibility that innovators actively sought institutional investors; and, our results do not run counter to this possibility. However, we claim that in the ownership structure of innovative firms, we find a heavy presence of institutional investors as well as 
stability in their stock ownership. This presence could be beneficial to both the investor and investee firms.

We test whether higher patent counts and citation counts are associated with increased institutional ownership. In Table 10, we regress future patent counts $\left(P C_{t+1}\right)$ and citation counts $\left(C C_{t+1}\right)$ on the change in PROP (represented by $\left.\triangle P R O P\right)$. Specifically, when the difference in PROP is positive (negative), it suggests that the proportion of shares held by institutional investors has increased (decreased) from the prior year. The dependent variable is the number of patent and citation counts in the following year. The coefficient of $\triangle P R O P$ (POSITIVE) is positive and highly significant under all scenarios. It suggests that firms that have experienced an increase in institutional ownership (i.e., $\triangle P R O P$ (POSITIVE)) are associated with a higher number of patent and citation counts, respectively.

\section{[INSERT TABLE 10 ABOUT HERE]}

\section{Conclusion}

Although some studies examine the relationship between institutional investors and firms' innovation and document that the existence of institutional ownership boost innovation, this study contributes to the literature by studying the link between institutional ownership stability and innovation activities. The findings suggest volatility in institutional shareholdings is inversely related to the investee firm's number of patent filings and patent citations. Our findings lend support to the hypothesis that stability (i.e., lower volatility) in institutional shareholdings assist firms to innovate.

We also find that—at the firm level—the higher the proportion of shares held by institutional investors, the higher the number of patent filings and citations. However, the results 
differ by types of institutional investors. To be more precise, the equity portfolios of banks, insurance companies and mutual funds contain more companies with more patents filed and patent citations than the portfolios of investment advisors and others. Active mutual funds (i.e., stock pickers and concentrated) are associated with investee companies with more patent filings and citations. Conversely, less active middle-of-the-road mutual funds (i.e., factor bets and moderately active) are associated with investee companies with less patent filings and citations. Closet indexers (i.e., passive mutual funds) and investee companies' patent filings and citations are not related. Taken altogether, although previous literature shows that the existence of institutional ownership is one of the determinants of firms' innovation, the results of this study suggest that the relationship differs based on the type of institutional investor examined.

Indeed, the possibility that investee firms are merely looking for investors with deep pockets to make significant investments necessary for R\&D intensive projects cannot be ruled out. It is vital for the investee firms to know that such investors would back them. Our main finding would serve to reassure managers that they benefit from the support of long-termoriented institutional investors who adopt a "buy and hold" investment philosophy as opposed to a "trading" philosophy. It should serve to reassure investee firms that there is little danger of institutional investors dumping their stock solely based on their innovation efforts and therefore firms should not be afraid to invest in such activities. Our findings also suggest that certain kinds of institutional investors pursue firms that are more innovative; have the ability to identify such firms; and, possibly, influence firms to become more innovative. 


\section{REFERENCES}

Aghion, P., Van Reenen, J., \& Zingales, L., (2013), Innovation and institutional ownership. American Economic Review 103, 277-304.

Almazan, A., Hartzell, J. C., \& Starks, L. T. (2005). Active institutional shareholders and costs of monitoring: Evidence from executive compensation. Financial Management, 34(4), 5-34.

Bailey, Jonathan and Godsall, Jonathan, "Short-Termism: Insights from Business Leaders, Findingsfrom a Global Survey of Business Leaders Commissioned by McKinsey \& Company and CPPInvestment Board," December 2013. CPPIB and McKinsey \& Company.

Bhagat, S. and Welch, I. (1995), "Corporate research and development investments: international Comparisons", Journal of Accounting and Economics, Vol. 19, pp. 443-70.

Blume, M. E., \& Keim, D. B., (2012). Institutional investors and stock market liquidity: trends and relationships. Available at SSRN 2147757.

Boehmer, E., \& Kelley, E. K., (2009). Institutional investors and the informational efficiency of prices. Review of Financial Studies, 22(9), 3563-3594.

Brickley, J. A., Lease, R. C., \& Smith, C. W. (1988). Ownership structure and voting on antitakeover amendments. Journal of financial economics, 20, 267-291.

Bushee, B. J. (1998). The Influence of Institutional Investors on Myopic R\&D Investment Behavior, Accounting Review, 73, 19 - 45.

Carleton, W., Nelson, J., and M. Weisbach, 1998, "The Influence of Institutions on Corporate Governance through Private Negotiations: Evidence from TIAA-CREF," Journal of Finance 53, 1335-1362

Chen, S., Sun, S. Y., \& Wu, D. (2010). Client importance, institutional improvements, and audit quality in China: An office and individual auditor level analysis. The Accounting Review, 85(1), 127-158.

Chen, X., Harford, J., Li, K. (2007). Monitoring: Which institutions matter? Journal of Financial Economics 86, 279-305.

Cho, C., Halford, J. T., Hsu, S., \& Ng, L. (2016). Do managers matter for corporate innovation? Journal of Corporate Finance, 36, 206-229.

Cockburn, I. and Henderson, R. (1999), "Public-private interaction and the productivity of pharmaceutical research", NBER Working Papers No. 6018, Cambridge, MA.

Cornaggia, J., Mao, Y., Tian, X., \& Wolfe, B. (2015). Does banking competition affect innovation? Journal of Financial Economics, 115(1), 189-209.

Cornett, M., Marcus, A., Saunders, A \& Tehranian, H., 2007. The impact of institutional ownership on corporate operating performance. Journal of Banking \& Finance, 31, 1771-1794. 
Cremers, K. M., \& Petajisto, A. (2009). How active is your fund manager? A new measure that predicts performance. Review of Financial Studies, 22(9), 3329-3365.

Elyasiani, E., and J. J. Jia, (2008), Institutional Ownership Stability and BHC Performance, Journal of Banking and Finance, 32 (9): 1767-1781.

Elyasiani, E., Jia, J. J., \& Mao, C. X., (2010), Institutional ownership stability and the cost of debt. Journal of Financial Markets, 13(4), 475-500.

Eng, L. L., \& Shackell, M., (2001), The implications of long-term performance plans and institutional ownership for firms' research and development (R\&D) investments. Journal of Accounting, Auditing \& Finance, 16(2), 117-139.

Fang, V. W., Tian, X., \& Tice, S., (2014), Does stock liquidity enhance or impede firm innovation? The Journal of Finance, 69(5), 2085-2125.

Francis, J., \& Smith, A., (1995), Agency costs and innovation some empirical evidence. Journal of Accounting and Economics, 19(2), 383-409.

Geroski, P. A., \& Machin, S. (1993). Innovation, profitability and growth over the business cycle. Empirica, 20(1), 35-50.

Gillan, S., Starks, L., 2000. Corporate governance proposals and shareholder activism: The role of institutional investors. Journal of Financial Economics 57, 275-305

Griliches, Zvi, Ariel Pakes, and Bronwyn Hall, (1988), The value of patents as indicators of inventive activity, NBER Working Paper 2083.

Grinold, R. C. (1999). Mean-variance and scenario-based approaches to portfolio selection. The Journal of Portfolio Management, 25(2), 10-22.

Guercio, D., Seery, L. \& Woidtke., 2008. Do boards pay attention when institutional investor activists "just vote no"? Journal of Financial Economics, 90, 84-103.

Hall, B. H., \& Lerner, J. (2010). The financing of R\&D and innovation. In Handbook of the Economics of Innovation (Vol. 1, pp. 609-639). North-Holland.

Hall, B. H., Jaffe, A. B., \& Trajtenberg, M. (2001). The NBER patent citation data file: Lessons, insights and methodological tools (No. w8498). National Bureau of Economic Research.

Hall, Bronwyn, Adam Jaffe, and Manuel Trajtenberg, (2005), Market value and patent citations, RAND Journal of Economics 36, 16-38.

Hartzell, J.C., Starks, L.T., 2003. Institutional investors and executive compensation. Journal of Finance 58 (6), 2351-2375.

He, J. J., \& Tian, X., (2013), The dark side of analyst coverage: The case of innovation. Journal of Financial Economics, 109(3), 856-878.

Holmstrom, Bengt, (1989), Agency costs and innovation. Journal of Economic Behavior and Organization 12, 305-327. 
Jarrell, G. A., K. Lehn and W. Marr (19 April 1985). Inrtitutional Ownership, Tender Offers and Longterm Investment. Office of the Chief Economist, Securities and Exchange Commission, Washington, DC.

Jory, S. R., Ngo, T., \& Sakaki, H. (2017). Institutional ownership stability and dividend payout policy. Managerial Finance, 43(10), 1170-1188.

Jafarinejad, M., Jory, S. R., \& Ngo, T. N. (2015). The effects of institutional ownership on the value and risk of diversified firms. International Review of Financial Analysis, 40, 207219.

Kota, S., Talbot-Zorn, J., \& Mahoney, T. (2018). How the U.S. Can Rebuild Its Capacity to Innovate. Harvard Business Review. Retrieved from https://hbr.org/2018/10/how-the-u-scan-rebuild-its-capacity-to-innovate

Lerner, Josh, Morten Sorensen, and Per Stromberg, (2011), Private equity and long-run investment: The case of innovation, Journal of Finance 66, 445-477.

McConnell, J.J., Servaes, H., 1990. Additional evidence on equity ownership and corporate value. Journal of Financial Economics 27, 595-612.

Petajisto, A. (2013). Active share and mutual fund performance. Financial Analysts Journal, 69(4), 73-93.

Porter, M. E. (1991). Capital disadvantage: America's failing capital investment system. Harvard business review, 70(5), 65-82.

Sakaki, H., Jackson, D., \& Jory, S. (2017). Institutional ownership stability and real earnings management. Review of Quantitative Finance and Accounting, 49(1), 227-244.

Sayili, K., Yilmaz, G., Dyer, D., \& Küllü, A. M. (2017). Style investing and firm innovation. Journal of Financial Stability, 32, 17-29.

Schumacher, J. (2016). How to Measure a Fund's Level of Active Management. Retrieved from http://www.morningstar.co.uk/uk/news/147726/how-to-measure-a-funds-level-of-activemanagement.aspx/

Seru, Amit, (2014), Firm boundaries matter: Evidence from conglomerates and R\&D activity, Journal of Financial Economics, 111, 381-405.

Smith, M., 1996. Shareholder activism by institutional investors: Evidence from CalPERS. Journal of Finance 51,227-252.

Solow, R. M., (1957), Technical change and the aggregate production function. The review of Economics and Statistics, 312-320.

Tian, X and Wang, T., (2014), Tolerance for failure and corporate innovation, Review of Financial Studies 27, 211-255.

Tonello, Matteo and Rabimov, Stephan Rahim, The 2010 Institutional Investment Report: Trends in Asset Allocation and Portfolio Composition (November 11, 2010). The Conference 
Board Research Report, No. R-1468-10-RR, 2010. Available at SSRN: https://ssrn.com/abstract $=1707512$

Trajtenberg, M. (1990). A penny for your quotes: patent citations and the value of innovations. The Rand Journal of Economics, 172-187. 
Table 1: Sample distribution

Panel A. Sample distribution by year

\begin{tabular}{cccccccc}
\hline Year & $\mathrm{N}$ & $\%$ & CUM & Year & $\mathrm{N}$ & $\%$ & CUM \\
\hline 1981 & 1,496 & 2.44 & 2.44 & 1994 & 2,865 & 4.68 & 47.9 \\
1982 & 1,508 & 2.46 & 4.91 & 1995 & 2,998 & 4.9 & 52.8 \\
1983 & 1,757 & 2.87 & 7.78 & 1996 & 3,329 & 5.44 & 58.24 \\
1984 & 1,891 & 3.09 & 10.86 & 1997 & 3,438 & 5.62 & 63.85 \\
1985 & 1,883 & 3.08 & 13.94 & 1998 & 3,467 & 5.66 & 69.52 \\
1986 & 2,015 & 3.29 & 17.23 & 1999 & 3,203 & 5.23 & 74.75 \\
1987 & 2,164 & 3.53 & 20.77 & 2000 & 3,233 & 5.28 & 80.03 \\
1988 & 2,245 & 3.67 & 24.43 & 2001 & 3,130 & 5.11 & 85.14 \\
1989 & 2,104 & 3.44 & 27.87 & 2002 & 3,129 & 5.11 & 90.25 \\
1990 & 2,188 & 3.57 & 31.44 & 2003 & 3,032 & 4.95 & 95.2 \\
1991 & 2,209 & 3.61 & 35.05 & 2004 & 2,937 & 4.8 & 100 \\
1992 & 2,411 & 3.94 & 38.99 & & & & \\
1993 & 2,593 & 4.24 & 43.22 & Total & 61,225 & 100 & \\
\hline
\end{tabular}

Panel B: Sample distribution by Fama and French 12-sector industry classification

\begin{tabular}{lccc}
\hline Industry & $\mathrm{N}$ & $\%$ & $\mathrm{CUM}$ \\
\hline Consumer Non-durables & 4,666 & 7.62 & 7.62 \\
Consumer durables & 2,297 & 3.75 & 11.37 \\
Manufacturing & 10,456 & 17.08 & 28.45 \\
Energy & 3,184 & 5.2 & 33.65 \\
Chemicals & 1,843 & 3.01 & 36.66 \\
Business Equipment & 13,554 & 22.14 & 58.8 \\
Telephone and Television & & & \\
Transmission & 1,673 & 2.73 & 61.53 \\
Wholesale, Retail, and Some Services & 8,010 & 13.08 & 74.61 \\
Healthcare, Medical Equipment, and Drugs & 6,066 & 9.91 & 84.52 \\
Others & 9,476 & 15.48 & 100 \\
$\quad$ Total & 61,225 & 100 & \\
\hline
\end{tabular}

This table describes the sample. Panel A presents sample distribution by year. Panel B shows the sample distribution by industry based on Fama and French 12-sector industry classification. N represents the number of firm-year observation. 
Table 2: Descriptive statistics of the sample

Panel A. Innovation variables

\begin{tabular}{lcccccc}
\hline Variable & $\mathbf{N}$ & $\mathbf{2 5 \%}$ & Median & Mean & $\mathbf{7 5 \%}$ & Std.Dev. \\
\hline PC & 61,225 & 0.000 & 0.000 & 0.574 & 0.693 & 1.142 \\
CC & 61,225 & 0.000 & 0.000 & 0.822 & 1.134 & 1.578 \\
\hline
\end{tabular}

Panel B. Institutional ownership variables

\begin{tabular}{lcccccc}
\hline Variable (\%) & $\mathbf{N}$ & $\mathbf{2 5 \%}$ & Median & Mean & $\mathbf{7 5 \%}$ & Std.Dev. \\
\hline IOV & 61,225 & 0.205 & 0.475 & 0.681 & 0.866 & 0.949 \\
BANKS & 61,225 & 0.786 & 2.653 & 4.794 & 6.753 & 5.920 \\
INSURANCE & 61,225 & 0.000 & 0.512 & 1.776 & 2.307 & 3.255 \\
INVESTMENT COMPANIES & 61,225 & 0.000 & 1.121 & 3.683 & 5.141 & 5.730 \\
INVESTMENT ADVISORS & 61,225 & 3.406 & 10.134 & 14.774 & 22.158 & 14.480 \\
OTHERS & 61,225 & 0.000 & 0.389 & 1.715 & 2.156 & 3.353 \\
\hline
\end{tabular}

Panel C. Control variables

\begin{tabular}{lcccccc}
\hline Variable & $\mathbf{N}$ & $\mathbf{2 5 \%}$ & Median & Mean & $\mathbf{7 5 \%}$ & Std.Dev. \\
\hline PROP (\%) & 61,225 & 4.385 & 11.378 & 16.838 & 24.360 & 16.439 \\
LN_SALE & 61,219 & 3.637 & 4.913 & 4.962 & 6.311 & 2.128 \\
RDTA & 61,225 & 0.000 & 0.000 & 0.048 & 0.054 & 0.118 \\
ROA & 61,225 & 0.053 & 0.121 & 0.078 & 0.179 & 0.598 \\
PPETA & 61,225 & 0.000 & 0.000 & 0.070 & 0.113 & 0.124 \\
LEV & 61,225 & 0.040 & 0.193 & 0.228 & 0.346 & 0.226 \\
CAPEXTA & 61,225 & 0.026 & 0.049 & 0.072 & 0.089 & 0.079 \\
HHI & 61,225 & 0.126 & 0.212 & 0.265 & 0.344 & 0.191 \\
Q & 61,225 & 1.041 & 1.383 & 1.995 & 2.110 & 2.499 \\
LN_AGE & 61,225 & 1.609 & 2.398 & 2.276 & 2.890 & 0.779 \\
\hline
\end{tabular}

This table shows descriptive statistics of the sample. PC is the natural logarithm of one plus the number of patents filed and eventually granted and $\mathrm{CC}$ is the natural logarithm of one plus the number of non-self-citations. IOV is calculated as the average standard deviation of shareholding proportion across all the institutional owners over a five-year period. BANKS, INSURANCE, INVESTMENT COMPANIES, INVESTMENT ADVISORS and OTHERS are calculated as the average percentage of firms' outstanding share held by banks, insurance, investment companies, investment advisors and others, respectively over the period. PROP is the average aggregate institutional shareholding proportion across the five-year period. LN_SALE is measured as the natural logarithm of total sales at the end of year t. RDTA is the ratio of research and development expenditures (set to zero if missing) to total assets at the end of year t. ROA is measured as operating income before depreciation divided by total assets at the end of year $t$. PPETA is measured as the ratio of property, plant, and equipment to total assets at the end of year $\mathrm{t}$. LEV is 
measured as the book value of debt (sum of long-term debt and debt in current liabilities) divided by total assets at the end of year t. CAPEXTA is measured as capital expenditures scaled by total assets at the end of year t. HHI is product market competition at the end of year t. Q is defined as Tobin's Q at the end of year t. LN_AGE is measured by the natural logarithm of one plus the number of years the firm is listed on Compustat. 
Table 3: Correlations

\begin{tabular}{|c|c|c|c|c|c|c|c|c|c|c|c|c|c|}
\hline & (1) & (2) & (3) & (4) & (5) & (6) & (7) & $(8)$ & (9) & (10) & $(11)$ & (12) & $(13)$ \\
\hline (1) & 1 & & & & & & & & & & & & \\
\hline$(2)$ & $0.9413 *$ & 1 & & & & & & & & & & & \\
\hline (3) & $-0.0692 *$ & $-0.058 *$ & 1 & & & & & & & & & & \\
\hline$(5)$ & $0.3575^{*}$ & $0.327 *$ & $-0.064 *$ & $\begin{array}{c}0.4361 * \\
-\end{array}$ & 1 & & & & & & & & \\
\hline (6) & $0.1346^{*}$ & $0.164 *$ & -0.003 & $0.0486^{*}$ & $-0.2931 *$ & $\begin{array}{l}1 \\
-\end{array}$ & & & & & & & \\
\hline (7) & $0.0191 *$ & $0.007 *$ & $-0.010 *$ & $0.0456^{*}$ & $0.1756^{*}$ & $\begin{array}{c}0.2177^{*} \\
-\end{array}$ & 1 & & & & & & \\
\hline$(8)$ & $0.0464 *$ & $0.030 *$ & $-0.028 *$ & $0.0590 *$ & $0.1669 *$ & $\begin{array}{c}0.1112^{*} \\
-\end{array}$ & $0.0472 *$ & 1 & & & & & \\
\hline (9) & $-0.0597 *$ & $-0.072 *$ & $0.0317^{*}$ & $\begin{array}{c}0.0231^{*} \\
-\end{array}$ & $0.1277 *$ & $\begin{array}{c}0.1381 * \\
-\end{array}$ & $-0.0251^{*}$ & $0.1110^{*}$ & 1 & & & & \\
\hline (10) & $-0.0438^{*}$ & $-0.071 *$ & $-0.025^{*}$ & $\begin{array}{c}0.0587 * \\
-\end{array}$ & $-0.0306^{*}$ & $0.0579 *$ & $0.0107 *$ & $0.0331 *$ & $0.096^{*}$ & & & & \\
\hline (11) & $0.0552 *$ & $0.082 *$ & $-0.072 *$ & $\begin{array}{c}0.0389 * \\
-\end{array}$ & $-0.1848^{*}$ & $\begin{array}{c}0.3349 * \\
-\end{array}$ & $-0.1699 *$ & $-0.0957 *$ & $-0.101 *$ & 1 & 1 & & \\
\hline (12) & $0.0464 *$ & $0.024 *$ & -0.003 & $0.0379 *$ & $0.0281 *$ & $\begin{array}{c}0.0952 * \\
-\end{array}$ & 0.0045 & $0.0374 *$ & $0.028^{*}$ & $-0.069 *$ & $-0.0554 *$ & 1 & \\
\hline (13) & $0.2075^{*}$ & $0.195^{*}$ & $-0.079 *$ & $0.1697 *$ & $0.3900^{*}$ & $0.1527^{*}$ & $0.0713 *$ & $0.2033 *$ & $0.043 *$ & $-0.129 *$ & $-0.1622 *$ & $0.0936 *$ & 1 \\
\hline
\end{tabular}

This table reports the correlation among variable used in this study. * indicates that the correlation is significant at least at the $10 \%$ level. The numbers in parentheses in the heading columns and rows represent:

(1) PC is the natural logarithm of one plus the number of patents filed and eventually granted (8) PPETA is measured as the ratio of property, plant, and equipment to total assets

(2) $\mathrm{CC}$ is the natural logarithm of one plus the number of non-self-citations (9) LEV is measured as the book value of debt (sum of long-term debt and debt in current liabilities) divided by total assets 
(3) OV is calculated as the average standard deviation of shareholding proportion across all the institutional owners over a fiveyear period (10) CAPEXTA is measured as capital expenditures scaled by total assets

(4) PROP is the average aggregate institutional shareholding proportion across the five-year period (11) Q is defined as Tobin's Q

(5) LN_SALE is measured as the natural logarithm of total sales

(12) HHI is product market competition

(6) RDTA is the ratio of research and development expenditures (set to zero if missing) to total assets (13) LN_AGE is measured by the natural logarithm of one plus the number of years the firm is listed on Compustat

ROA is measured as operating income before depreciation divided by total assets 
Table 4: Number of Patents and Citations Sorted by Institutional Ownership Proportion and Stability

Panel A: Number of Patents (PC) Sorted by Institutional Ownership Proportion and Stability

\begin{tabular}{crccccl} 
& \multicolumn{5}{c}{ PROP High } \\
\cline { 3 - 7 } & 1 & 1 & 2 & 3 & H-L & T-statistics \\
\hline \multirow{2}{nyyyyyy}{ IOV Low } & 2 & 0.237 & 1.147 & 1.718 & 1.246 & $-49.34^{* * *}$ \\
& 3 & 0.165 & 0.278 & 0.780 & 0.544 & $-30.5^{* * *}$ \\
IOV High & H-L & -0.307 & -0.869 & -1.221 & & \\
& & $15.49^{* * *}$ & $41.75^{* * *}$ & $45.93^{* * *}$ & & \\
\hline T-statistics & & & &
\end{tabular}

Panel B: Number of Citations (CC) Sorted by Institutional Ownership Proportion and Stability

\begin{tabular}{crccccc} 
& \multicolumn{5}{c}{ PROP Low High } \\
\cline { 3 - 7 } & & 1 & 2 & 3 & H-L & T-statistics \\
\hline \multirow{2}{*}{ IOV Low } & 1 & 0.574 & 1.460 & 2.487 & 1.912 & $-59.22^{* * *}$ \\
& 2 & 0.324 & 0.663 & 1.277 & 0.953 & $-34.8^{* * *}$ \\
IOV High & 3 & 0.226 & 0.400 & 0.809 & 0.582 & $-19.61^{* * *}$ \\
& H-L & -0.348 & -1.061 & -1.678 & & \\
\hline T-statistics & & $14.8^{* * *}$ & $40.48^{* * *}$ & $43.67^{* * *}$ & & \\
\hline
\end{tabular}

This table reports the average number of patents and citations of 9 portfolios. The sample is classified into terciles based on the aggregate institutional ownership proportion in each year. Each tercile is divided into three groups based on the institutional ownership stability. Each cell indicates the average of the number of patents (citations) for each portfolio. The last two columns/rows present the average number of patents difference between the highest and lowest portfolio in the same IOV/PROP tercile and T-statistics, respectively. *, **, and *** indicate statistical significance at the $10 \%, 5 \%$, and $1 \%$ level, respectively. 
Table 5 - OLS Regressions

\begin{tabular}{|c|c|c|c|c|c|c|}
\hline \multirow[b]{2}{*}{ Dependent Variable } & \multicolumn{3}{|c|}{$\begin{array}{c}\text { Panel A } \\
\text { Patent Count }\end{array}$} & \multicolumn{3}{|c|}{$\begin{array}{c}\text { Panel B } \\
\text { Citation Count }\end{array}$} \\
\hline & $\begin{array}{l}P C_{t+1} \\
(\text { Model 1) }\end{array}$ & $\begin{array}{l}P C_{t+2} \\
(\text { Model 2) }\end{array}$ & $\begin{array}{l}P C_{t+3} \\
\text { (Model 3) }\end{array}$ & $\begin{array}{l}C C_{t+1} \\
(\text { Model 4) }\end{array}$ & $\begin{array}{l}C C_{t+2} \\
(\text { Model 5) }\end{array}$ & $\begin{array}{l}C C_{t+3} \\
(\text { Model 6) }\end{array}$ \\
\hline IOV & $\begin{array}{c}-3.033 * * * \\
(-6.865)\end{array}$ & $\begin{array}{c}-3.519 * * * \\
(-7.760)\end{array}$ & $\begin{array}{c}-3.663 * * * \\
(-7.788)\end{array}$ & $\begin{array}{c}-4.281 * * * \\
(-3.365)\end{array}$ & $\begin{array}{c}-4.393 * * * \\
(-6.952)\end{array}$ & $\begin{array}{c}-2.832 * * * \\
(-1.366)\end{array}$ \\
\hline$P C_{t-1}$ & $\begin{array}{l}1.120 * * * \\
(92.595)\end{array}$ & $\begin{array}{l}1.084 * * * \\
(73.360)\end{array}$ & $\begin{array}{c}1.087 * * * \\
(60.764)\end{array}$ & $\begin{array}{l}1.435 * * * \\
(26.232)\end{array}$ & $\begin{array}{l}1.389 * * * \\
(29.289)\end{array}$ & $\begin{array}{l}0.009^{* *} \\
(2.473)\end{array}$ \\
\hline$C C_{t-1}$ & $\begin{array}{l}0.172 * * * \\
(19.984)\end{array}$ & $\begin{array}{l}0.137 * * * \\
(12.095)\end{array}$ & $\begin{array}{c}0.139 * * * \\
(9.545)\end{array}$ & $\begin{array}{c}0.193 * * * \\
(14.774)\end{array}$ & $\begin{array}{l}0.176^{* * * *} \\
(12.513)\end{array}$ & $\begin{array}{l}0.985 * * * \\
(22.581)\end{array}$ \\
\hline PROP & $\begin{array}{c}0.116 \\
(1.177)\end{array}$ & $\begin{array}{c}0.177 * * * \\
(10.228)\end{array}$ & $\begin{array}{c}0.173 * * * \\
(9.789)\end{array}$ & $\begin{array}{c}0.505^{* * * *} \\
(4.099)\end{array}$ & $\begin{array}{c}0.452 * * * \\
(3.461)\end{array}$ & $\begin{array}{c}0.423 * * * \\
(3.102)\end{array}$ \\
\hline LN_SALE & $\begin{array}{l}0.287 * * * \\
(19.532)\end{array}$ & $\begin{array}{l}0.304^{* * *} \\
(19.123)\end{array}$ & $\begin{array}{c}0.315^{* * *} \\
(18.273)\end{array}$ & $\begin{array}{l}0.328^{* * *} \\
(20.141)\end{array}$ & $\begin{array}{c}0.341^{* * *} \\
(19.847)\end{array}$ & $\begin{array}{c}0.346^{* * * *} \\
(18.782)\end{array}$ \\
\hline RDTA & $\begin{array}{c}1.746^{* * * *} \\
(9.801)\end{array}$ & $\begin{array}{c}1.828^{* * *} \\
(9.450)\end{array}$ & $\begin{array}{c}1.905^{* * *} \\
(8.050)\end{array}$ & $\begin{array}{l}2.440 * * * \\
(10.392)\end{array}$ & $\begin{array}{c}2.494 * * * \\
(10.416)\end{array}$ & $\begin{array}{c}2.474 * * * \\
(8.695)\end{array}$ \\
\hline ROA & $\begin{array}{l}-0.108 \\
(-1.285)\end{array}$ & $\begin{array}{c}-0.250 * * * \\
(-3.629)\end{array}$ & $\begin{array}{c}-0.288^{* * *} \\
(-3.301)\end{array}$ & $\begin{array}{c}-0.059 \\
(-0.541)\end{array}$ & $\begin{array}{c}-0.253 * * * \\
(-3.016)\end{array}$ & $\begin{array}{c}-0.308 * * * \\
(-3.013)\end{array}$ \\
\hline PPETA & $\begin{array}{c}0.055 \\
(0.569)\end{array}$ & $\begin{array}{l}0.090 \\
(0.855)\end{array}$ & $\begin{array}{c}0.136 \\
(1.172)\end{array}$ & $\begin{array}{c}-0.029 \\
(-0.256)\end{array}$ & $\begin{array}{c}0.023 \\
(0.193)\end{array}$ & $\begin{array}{c}0.092 \\
(0.724)\end{array}$ \\
\hline LEV & $\begin{array}{c}-0.186^{* * *} \\
(-4.004)\end{array}$ & $\begin{array}{c}-0.146 * * * \\
(-2.940)\end{array}$ & $\begin{array}{l}-0.109^{*} \\
(-1.939)\end{array}$ & $\begin{array}{c}-0.215^{* * *} \\
(-3.570)\end{array}$ & $\begin{array}{c}-0.158^{* *} \\
(-2.567)\end{array}$ & $\begin{array}{c}-0.104 \\
(-1.557)\end{array}$ \\
\hline CAPEXTA & $\begin{array}{c}0.173 \\
(1.263)\end{array}$ & $\begin{array}{c}0.127 \\
(0.951)\end{array}$ & $\begin{array}{c}0.036 \\
(0.225)\end{array}$ & $\begin{array}{c}0.072 \\
(0.422)\end{array}$ & $\begin{array}{c}0.012 \\
(0.076)\end{array}$ & $\begin{array}{c}-0.111 \\
(-0.606)\end{array}$ \\
\hline Q & $\begin{array}{c}0.031 * * * \\
(4.556)\end{array}$ & $\begin{array}{c}0.036^{* * * *} \\
(5.161)\end{array}$ & $\begin{array}{c}0.038 * * * \\
(4.778)\end{array}$ & $\begin{array}{c}0.048^{* * *} \\
(5.066)\end{array}$ & $\begin{array}{c}0.051 * * * \\
(5.228)\end{array}$ & $\begin{array}{c}0.051 * * * \\
(4.934)\end{array}$ \\
\hline HHI & $\begin{array}{c}-0.356 \\
(-1.492)\end{array}$ & $\begin{array}{c}-0.337 \\
(-1.297)\end{array}$ & $\begin{array}{c}-0.356 \\
(-1.254)\end{array}$ & $\begin{array}{l}-0.535^{*} \\
(-1.878)\end{array}$ & $\begin{array}{c}-0.486 \\
(-1.619)\end{array}$ & $\begin{array}{c}-0.490 \\
(-1.536)\end{array}$ \\
\hline HHI2 & $\begin{array}{l}0.631^{* *} \\
(2.235)\end{array}$ & $\begin{array}{l}0.631 * * \\
(2.067)\end{array}$ & $\begin{array}{c}0.666^{* *} \\
(2.011)\end{array}$ & $\begin{array}{l}0.807 * * \\
(2.443)\end{array}$ & $\begin{array}{l}0.779 * * \\
(2.243)\end{array}$ & $\begin{array}{l}0.801 * * \\
(2.186)\end{array}$ \\
\hline LN_AGE & $\begin{array}{c}0.094 * * * \\
(5.749)\end{array}$ & $\begin{array}{c}0.124 * * * \\
(6.187)\end{array}$ & $\begin{array}{c}0.153 * * * \\
(6.316)\end{array}$ & $\begin{array}{c}0.100 * * * \\
(4.627)\end{array}$ & $\begin{array}{c}0.129 * * * \\
(5.073)\end{array}$ & $\begin{array}{c}0.158 * * * \\
(5.353)\end{array}$ \\
\hline Year & YES & YES & YES & YES & YES & YES \\
\hline Industry & YES & YES & YES & YES & YES & YES \\
\hline No. of obs. & 48,289 & 40,905 & 34,538 & 48,289 & 40,905 & 34,538 \\
\hline Adj.R2 & 0.178 & 0.191 & 0.143 & 0.167 & 0.182 & 0.168 \\
\hline
\end{tabular}

This table reports the results from the OLS regressions of the patent count (Panel A which consists of Models 1, 2, and 3) and patent citations (Panel B which consists of Models 4, 5, and 6). The dependent variables are $\mathrm{PC}$, which is the natural logarithm of one plus number of patents filed and eventually granted (Panel A) and CC which is the natural logarithm of one plus the number of nonself-citations (Panel B). IOV is calculated as the average standard deviation of shareholding proportion across all the institutional owners over a five-year period. The definitions of control variables are provided in Table $2 . *{ }^{* *}$ and $* * *$ indicate statistical significance at the $10 \%, 5 \%$, and $1 \%$ level, respectively. 
Table 6: Fixed-effect Regressions

\begin{tabular}{|c|c|c|c|c|c|c|}
\hline & \multicolumn{3}{|c|}{ Panel A: Patent Count } & \multicolumn{3}{|c|}{ Panel B: Citation Count } \\
\hline & $\begin{array}{c}P C_{t+1} \\
(1)\end{array}$ & $\begin{array}{c}P C_{t+2} \\
\quad(2)\end{array}$ & $\begin{array}{c}P C_{t+3} \\
(3) \\
\end{array}$ & $\begin{array}{c}C C_{t+1} \\
(4)\end{array}$ & $\begin{array}{r}C C_{t+2} \\
(5) \\
\end{array}$ & $\begin{array}{r}C C_{t+3} \\
(6) \\
\end{array}$ \\
\hline IOV_t & $\begin{array}{c}-1.015^{* *} \\
(-2.016)\end{array}$ & $\begin{array}{c}-0.932 * * * \\
(-1.594)\end{array}$ & $\begin{array}{c}-1.834 * * * \\
(-2.729)\end{array}$ & $\begin{array}{c}-4.045^{* * *} \\
(-5.143)\end{array}$ & $\begin{array}{c}-2.959 * * * \\
(-3.421)\end{array}$ & $\begin{array}{r}-3.658 * * * \\
(-3.919)\end{array}$ \\
\hline$P C_{t-1}$ & $\begin{array}{c}0.659 * * * \\
(0.138)\end{array}$ & $\begin{array}{c}0.341 * * \\
(0.164)\end{array}$ & $\begin{array}{c}0.264 \\
(0.150)\end{array}$ & $\begin{array}{c}0.357 * * * \\
(0.116)\end{array}$ & $\begin{array}{c}0.535^{* *} \\
(0.220)\end{array}$ & $\begin{array}{c}0.477 \\
(0.082)\end{array}$ \\
\hline$C C_{t-1}$ & $\begin{array}{c}0.674 * * * \\
(0.082)\end{array}$ & $\begin{array}{c}0.192 * * * \\
(0.060)\end{array}$ & $\begin{array}{c}0.091 \\
(0.061)\end{array}$ & $\begin{array}{c}0.207 * * \\
(0.091)\end{array}$ & $\begin{array}{c}0.029 \\
(0.109)\end{array}$ & $\begin{array}{c}0.101 \\
(0.133)\end{array}$ \\
\hline PROP & $\begin{array}{c}0.375^{* * *} \\
(11.339)\end{array}$ & $\begin{array}{c}0.441 * * * \\
(12.054)\end{array}$ & $\begin{array}{c}0.521 * * * \\
(13.069)\end{array}$ & $\begin{array}{l}1.133 * * * \\
(21.948)\end{array}$ & $\begin{array}{c}1.079 * * * \\
(19.930)\end{array}$ & $\begin{array}{c}1.087 * * * \\
(19.641)\end{array}$ \\
\hline LN_SALE & $\begin{array}{c}0.144 * * * \\
(27.639)\end{array}$ & $\begin{array}{c}0.141^{* * *} \\
(23.375)\end{array}$ & $\begin{array}{c}0.112^{* * *} \\
(16.344)\end{array}$ & $\begin{array}{c}0.180 * * * \\
(22.093)\end{array}$ & $\begin{array}{c}0.168^{* * *} \\
(18.845)\end{array}$ & $\begin{array}{c}0.117 * * * \\
(12.294)\end{array}$ \\
\hline RDTA & $\begin{array}{c}-0.011 \\
(-0.222)\end{array}$ & $\begin{array}{c}-0.146^{* * *} \\
(-2.595)\end{array}$ & $\begin{array}{c}-0.225 * * * \\
(-3.537)\end{array}$ & $\begin{array}{c}-0.191 * * * \\
(-2.580)\end{array}$ & $\begin{array}{c}-0.337 * * * \\
(-4.051)\end{array}$ & $\begin{array}{c}-0.431 * * * \\
(-4.869)\end{array}$ \\
\hline ROA & $\begin{array}{c}-0.227 * * * \\
(-9.943)\end{array}$ & $\begin{array}{c}-0.252 * * * \\
(-9.332)\end{array}$ & $\begin{array}{c}-0.256 * * * \\
(-8.421)\end{array}$ & $\begin{array}{c}-0.311 * * * \\
(-8.709)\end{array}$ & $\begin{array}{c}-0.342 * * * \\
(-8.561)\end{array}$ & $\begin{array}{c}-0.331 * * * \\
(-7.818)\end{array}$ \\
\hline PPETA & $\begin{array}{l}-0.068^{*} \\
(-1.788)\end{array}$ & $\begin{array}{c}-0.069 \\
(-1.635)\end{array}$ & $\begin{array}{c}-0.034 \\
(-0.704)\end{array}$ & $\begin{array}{c}-0.236 * * * \\
(-3.975)\end{array}$ & $\begin{array}{c}-0.214 * * * \\
(-3.419)\end{array}$ & $\begin{array}{c}-0.140 * * \\
(-2.103)\end{array}$ \\
\hline LEV & $\begin{array}{c}-0.058 * * * \\
(-3.056)\end{array}$ & $\begin{array}{c}0.035 \\
(1.594)\end{array}$ & $\begin{array}{c}0.060 * * \\
(2.496)\end{array}$ & $\begin{array}{c}0.026 \\
(0.856)\end{array}$ & $\begin{array}{c}0.151^{* * *} \\
(4.663)\end{array}$ & $\begin{array}{c}0.173 * * * \\
(5.152)\end{array}$ \\
\hline CAPEXTA & $\begin{array}{c}-0.146^{* * *} \\
(-3.007)\end{array}$ & $\begin{array}{c}-0.250 * * * \\
(-4.442)\end{array}$ & $\begin{array}{c}-0.305 * * * \\
(-4.678)\end{array}$ & $\begin{array}{c}-0.254 * * * \\
(-3.347)\end{array}$ & $\begin{array}{c}-0.351 * * * \\
(-4.212)\end{array}$ & $\begin{array}{c}-0.403 * * * \\
(-4.443)\end{array}$ \\
\hline Q & $\begin{array}{c}-0.001 \\
(-0.445)\end{array}$ & $\begin{array}{c}-0.002 \\
(-1.275)\end{array}$ & $\begin{array}{c}-0.000 \\
(-0.195)\end{array}$ & $\begin{array}{c}-0.001 \\
(-0.473)\end{array}$ & $\begin{array}{c}-0.006^{* *} \\
(-2.108)\end{array}$ & $\begin{array}{c}-0.001 \\
(-0.330)\end{array}$ \\
\hline HHI & $\begin{array}{c}0.024 \\
(0.289)\end{array}$ & $\begin{array}{c}0.078 \\
(0.851)\end{array}$ & $\begin{array}{c}0.047 \\
(0.462)\end{array}$ & $\begin{array}{c}-0.319 * * \\
(-2.472)\end{array}$ & $\begin{array}{c}-0.196 \\
(-1.443)\end{array}$ & $\begin{array}{c}-0.211 \\
(-1.506)\end{array}$ \\
\hline HHI squared & $\begin{array}{c}0.058 \\
(0.697)\end{array}$ & $\begin{array}{c}0.012 \\
(0.127)\end{array}$ & $\begin{array}{c}0.028 \\
(0.277)\end{array}$ & $\begin{array}{c}0.367 * * * \\
(2.824)\end{array}$ & $\begin{array}{l}0.251^{*} \\
(1.844)\end{array}$ & $\begin{array}{l}0.248^{*} \\
(1.775)\end{array}$ \\
\hline LN_AGE & $\begin{array}{c}0.103 * * * \\
(7.166)\end{array}$ & $\begin{array}{c}0.176^{* * *} \\
(9.083)\end{array}$ & $\begin{array}{c}0.290 * * * \\
(11.301)\end{array}$ & $\begin{array}{c}-0.020 \\
(-0.877)\end{array}$ & $\begin{array}{c}0.083 * * * \\
(2.897)\end{array}$ & $\begin{array}{c}0.241 * * * \\
(6.782)\end{array}$ \\
\hline Year & YES & YES & YES & YES & YES & YES \\
\hline Industry & NO & NO & NO & NO & NO & NO \\
\hline No. of obs. & 48,289 & 40,905 & 34,538 & 48,289 & 40,905 & 34,538 \\
\hline Adj.R-squared & 0.126 & 0.117 & 0.702 & 0.164 & 0.181 & 0.167 \\
\hline
\end{tabular}

This table reports the results from the fixed-effect regressions of the patent count (Panel A) and patent citations (Panel B). The dependent variables are PC, which is the natural logarithm of one 
plus number of patents filed and eventually granted (Panel A) and $\mathrm{CC}$, which is the natural logarithm of one plus the number of non-self-citations (Panel B). IOV is calculated as the average standard deviation of shareholding proportion across all the institutional owners over a five-year period. The definitions of control variables are provided in Table $2 . * * *$ and $* * *$ indicate statistical significance at the $10 \%, 5 \%$, and $1 \%$ level, respectively. 
Table 7: Fixed-effect regressions for different types of institutional investors

\begin{tabular}{|c|c|c|c|c|c|c|}
\hline & \multicolumn{3}{|c|}{ Panel A: Patent Count } & \multicolumn{3}{|c|}{ Panel B: Citation Count } \\
\hline & $\begin{array}{c}P C_{t+1} \\
(1)\end{array}$ & $\begin{array}{r}P C_{t+2} \\
\quad(2)\end{array}$ & $\begin{array}{r}P C_{t+3} \\
(3) \\
\end{array}$ & $\begin{array}{c}C C_{t+1} \\
(4) \\
\end{array}$ & $\begin{array}{r}C C_{t+2} \\
\quad(5)\end{array}$ & $\begin{array}{r}C C_{t+3} \\
(6)\end{array}$ \\
\hline BANKS & $\begin{array}{c}0.250^{* * * *} \\
(3.547)\end{array}$ & $\begin{array}{c}0.258^{* * *} \\
(3.319)\end{array}$ & $\begin{array}{c}0.346^{* * *} \\
(4.104)\end{array}$ & $\begin{array}{c}0.747^{* * *} \\
(6.795)\end{array}$ & $\begin{array}{c}0.627 * * * \\
(5.454)\end{array}$ & $\begin{array}{c}0.606^{* * *} \\
(5.170)\end{array}$ \\
\hline INSURANCE & $\begin{array}{c}0.285 * * * \\
(2.593)\end{array}$ & $\begin{array}{c}0.245^{* *} \\
(2.006)\end{array}$ & $\begin{array}{c}0.414 * * * \\
(3.103)\end{array}$ & $\begin{array}{c}0.516^{* * *} \\
(3.011)\end{array}$ & $\begin{array}{c}0.433^{* *} \\
(2.399)\end{array}$ & $\begin{array}{c}0.536^{* * *} \\
(2.895)\end{array}$ \\
\hline MUTUAL FUNDS & $\begin{array}{c}0.218^{* * *} \\
(3.185)\end{array}$ & $\begin{array}{c}0.216^{* * *} \\
(2.853)\end{array}$ & $\begin{array}{c}0.190^{* *} \\
(2.305)\end{array}$ & $\begin{array}{c}0.525^{* * *} \\
(4.915)\end{array}$ & $\begin{array}{c}0.485^{* * *} \\
(4.330)\end{array}$ & $\begin{array}{c}0.464 * * * \\
(4.042)\end{array}$ \\
\hline ADVISORS & $\begin{array}{l}-0.072 * \\
(-1.891)\end{array}$ & $\begin{array}{c}-0.054 \\
(-1.290)\end{array}$ & $\begin{array}{l}-0.089^{*} \\
(-1.939)\end{array}$ & $\begin{array}{c}-0.166^{* * *} \\
(-2.808)\end{array}$ & $\begin{array}{c}-0.080 \\
(-1.294)\end{array}$ & $\begin{array}{c}-0.135^{* *} \\
(-2.126)\end{array}$ \\
\hline OTHERS & $\begin{array}{c}0.257 \\
(2.203)\end{array}$ & $\begin{array}{c}0.279 \\
(2.132)\end{array}$ & $\begin{array}{c}0.205 \\
(1.414)\end{array}$ & $\begin{array}{c}-0.016 \\
(-0.087)\end{array}$ & $\begin{array}{c}0.079 \\
(0.408)\end{array}$ & $\begin{array}{c}0.088 \\
(0.437)\end{array}$ \\
\hline$P C_{t-1}$ & $\begin{array}{c}0.466^{* * * *} \\
(0.165)\end{array}$ & $\begin{array}{c}0.271^{* *} \\
(0.108)\end{array}$ & $\begin{array}{l}0.0505 \\
(0.131)\end{array}$ & $\begin{array}{c}0.132 * * * \\
(0.0395)\end{array}$ & $\begin{array}{l}0.0870^{*} \\
(0.0523)\end{array}$ & $\begin{array}{c}0.0157 \\
(0.0460)\end{array}$ \\
\hline$C C_{t-1}$ & $\begin{array}{c}0.141 * * * \\
(0.0428)\end{array}$ & $\begin{array}{l}0.136^{* *} \\
(0.0643)\end{array}$ & $\begin{array}{c}0.213 \\
(0.141)\end{array}$ & $\begin{array}{c}0.162^{* * *} \\
(0.0477)\end{array}$ & $\begin{array}{l}0.669^{*} \\
(0.400)\end{array}$ & $\begin{array}{c}0.604 \\
(0.479)\end{array}$ \\
\hline PROP & $\begin{array}{c}0.264 * * * \\
(5.528)\end{array}$ & $\begin{array}{c}0.322 * * * \\
(6.174)\end{array}$ & $\begin{array}{c}0.392 * * * \\
(6.965)\end{array}$ & $\begin{array}{c}0.876^{* * *} \\
(11.730)\end{array}$ & $\begin{array}{c}0.817 * * * \\
(10.605)\end{array}$ & $\begin{array}{c}0.853^{* * *} \\
(10.912)\end{array}$ \\
\hline LN_SALE & $\begin{array}{l}0.139 * * * \\
(26.259)\end{array}$ & $\begin{array}{c}0.136^{* * *} \\
(22.060)\end{array}$ & $\begin{array}{c}0.106^{* * *} \\
(15.123)\end{array}$ & $\begin{array}{c}0.171^{* * *} \\
(20.630)\end{array}$ & $\begin{array}{c}0.158^{* * *} \\
(17.412)\end{array}$ & $\begin{array}{c}0.107^{* * *} \\
(11.021)\end{array}$ \\
\hline RDTA & $\begin{array}{c}-0.006 \\
(-0.132)\end{array}$ & $\begin{array}{c}-0.139^{* *} \\
(-2.476)\end{array}$ & $\begin{array}{c}-0.218^{* * *} \\
(-3.427)\end{array}$ & $\begin{array}{c}-0.181 * * \\
(-2.445)\end{array}$ & $\begin{array}{c}-0.321^{* * *} \\
(-3.863)\end{array}$ & $\begin{array}{c}-0.416^{* * *} \\
(-4.700)\end{array}$ \\
\hline ROA & $\begin{array}{c}-0.224 * * * \\
(-9.816)\end{array}$ & $\begin{array}{c}-0.249 * * * \\
(-9.205)\end{array}$ & $\begin{array}{c}-0.253^{* * *} \\
(-8.292)\end{array}$ & $\begin{array}{c}-0.308 * * * \\
(-8.637)\end{array}$ & $\begin{array}{c}-0.340 * * * \\
(-8.497)\end{array}$ & $\begin{array}{c}-0.326^{* * *} \\
(-7.714)\end{array}$ \\
\hline PPETA & $\begin{array}{l}-0.065^{*} \\
(-1.695)\end{array}$ & $\begin{array}{c}-0.064 \\
(-1.514)\end{array}$ & $\begin{array}{c}-0.028 \\
(-0.590)\end{array}$ & $\begin{array}{c}-0.230 * * * \\
(-3.868)\end{array}$ & $\begin{array}{c}-0.205^{* * *} \\
(-3.271)\end{array}$ & $\begin{array}{c}-0.131 * * \\
(-1.973)\end{array}$ \\
\hline LEV & $\begin{array}{c}-0.056 * * * \\
(-2.950)\end{array}$ & $\begin{array}{l}0.039^{*} \\
(1.753)\end{array}$ & $\begin{array}{c}0.064 * * * \\
(2.634)\end{array}$ & $\begin{array}{c}0.029 \\
(0.966)\end{array}$ & $\begin{array}{c}0.159^{* * *} \\
(4.884)\end{array}$ & $\begin{array}{c}0.179 * * * \\
(5.329)\end{array}$ \\
\hline CAPEXTA & $\begin{array}{c}-0.150 * * * \\
(-3.083)\end{array}$ & $\begin{array}{c}-0.255^{* * *} \\
(-4.526)\end{array}$ & $\begin{array}{c}-0.310^{* * *} \\
(-4.746)\end{array}$ & $\begin{array}{c}-0.261 * * * \\
(-3.448)\end{array}$ & $\begin{array}{c}-0.362 * * * \\
(-4.348)\end{array}$ & $\begin{array}{c}-0.410 * * * \\
(-4.527)\end{array}$ \\
\hline Q & $\begin{array}{c}-0.001 \\
(-0.608)\end{array}$ & $\begin{array}{l}-0.003 \\
(-1.477)\end{array}$ & $\begin{array}{l}-0.001 \\
(-0.401)\end{array}$ & $\begin{array}{c}-0.002 \\
(-0.818)\end{array}$ & $\begin{array}{c}-0.007 * * \\
(-2.511)\end{array}$ & $\begin{array}{c}-0.002 \\
(-0.683)\end{array}$ \\
\hline HHI & $\begin{array}{c}0.027 \\
(0.329)\end{array}$ & $\begin{array}{c}0.084 \\
(0.917)\end{array}$ & $\begin{array}{c}0.054 \\
(0.541)\end{array}$ & $\begin{array}{c}-0.311 * * \\
(-2.408)\end{array}$ & $\begin{array}{c}-0.181 \\
(-1.336)\end{array}$ & $\begin{array}{c}-0.196 \\
(-1.402)\end{array}$ \\
\hline HHI squared & $\begin{array}{c}0.057 \\
(0.681)\end{array}$ & $\begin{array}{c}0.008 \\
(0.085)\end{array}$ & $\begin{array}{c}0.022 \\
(0.214)\end{array}$ & $\begin{array}{c}0.362 * * * \\
(2.786)\end{array}$ & $\begin{array}{l}0.240^{*} \\
(1.763)\end{array}$ & $\begin{array}{l}0.236^{*} \\
(1.687)\end{array}$ \\
\hline LN_AGE & $\begin{array}{c}0.103 * * * \\
(7.140)\end{array}$ & $\begin{array}{c}0.179 * * * \\
(9.179)\end{array}$ & $\begin{array}{c}0.298 * * * \\
(11.587)\end{array}$ & $\begin{array}{c}-0.019 \\
(-0.862)\end{array}$ & $\begin{array}{c}0.087 * * * \\
(3.027)\end{array}$ & $\begin{array}{c}0.255^{* * *} \\
(7.155)\end{array}$ \\
\hline Year & YES & YES & YES & YES & YES & YES \\
\hline Industry & $\mathrm{NO}$ & NO & $\mathrm{NO}$ & NO & NO & $\mathrm{NO}$ \\
\hline No. of obs. & 48,289 & 40,905 & 34,538 & 48,289 & 40,905 & 34,538 \\
\hline Adj.R-squared & 0.125 & 0.116 & 0.111 & 0.191 & 0.175 & 0.193 \\
\hline
\end{tabular}


This table reports the results of the fixed effect regressions of the patent count (Panel A) and patent citations (Panel B). The dependent variables are PC, which is the natural logarithm of one plus number of patents filed and eventually granted (Panel A) and CC, which is the natural logarithm of one plus the number of non-self-citations (Panel B). Institutional owners are classified into five groups based upon the classification of Thomson Reuters updated by Professor Bushee. BANKS, INSURANCE, INVESTMENT COMPANIES, INVESTMENT ADVISORS and OTHERS are calculated as the average percentage of firms i outstanding shares held by banks, insurance, investment companies, investment advisors and others, respectively at the end of year t. The definitions of control variables are provided in Table $2 . *, * *$ and $* * *$ indicate statistical significance at the $10 \%, 5 \%$, and $1 \%$ level, respectively. 


\section{Table 8: Fixed-effect regressions for different types of institutional investors}

\begin{tabular}{|c|c|c|c|c|c|c|}
\hline \multirow[b]{2}{*}{ Dependent Variable } & \multicolumn{3}{|c|}{ Panel A: Patent Count } & \multicolumn{3}{|c|}{ Panel B: Citation Count } \\
\hline & $\begin{array}{c}P C_{t+1} \\
(1)\end{array}$ & $\begin{array}{r}P C_{t+2} \\
(2)\end{array}$ & $\begin{array}{r}P C_{t+3} \\
(3)\end{array}$ & $\begin{array}{c}C C_{t+1} \\
(4)\end{array}$ & $\begin{array}{r}C C_{t+2} \\
(5)\end{array}$ & $\begin{array}{r}C C_{t+3} \\
(6) \\
\end{array}$ \\
\hline STOCK PICKERS & $\begin{array}{c}0.861 * * \\
(0.336)\end{array}$ & $\begin{array}{l}0.755^{*} \\
(0.417)\end{array}$ & $\begin{array}{l}0.761^{*} \\
(0.458)\end{array}$ & $\begin{array}{c}0.632 * * * \\
(0.0954)\end{array}$ & $\begin{array}{c}0.620^{* *} \\
(0.280)\end{array}$ & $\begin{array}{c}0.746^{* * *} \\
(0.0247)\end{array}$ \\
\hline CONCENTRATED & $\begin{array}{c}0.467 * * * \\
(0.0606)\end{array}$ & $\begin{array}{c}0.327^{* * *} * \\
(0.0535)\end{array}$ & $\begin{array}{c}0.265^{* * *} * \\
(0.0690)\end{array}$ & $\begin{array}{c}0.320 * * * \\
(0.0794)\end{array}$ & $\begin{array}{c}0.303 * * * \\
(0.251)\end{array}$ & $\begin{array}{c}0.272^{* * *} \\
(0.0398)\end{array}$ \\
\hline FACTOR BETS & $\begin{array}{c}-0.163 * * * \\
(0.0496)\end{array}$ & $\begin{array}{l}-0.152^{* *} \\
(0.0633)\end{array}$ & $\begin{array}{l}-0.037 * \\
(0.249)\end{array}$ & $\begin{array}{c}-0.133 * * * \\
(0.132)\end{array}$ & $\begin{array}{c}-0.145^{* *} \\
(0.248)\end{array}$ & $\begin{array}{c}-0.209^{*} \\
(0.120)\end{array}$ \\
\hline MODERATELY ACTIVE & $\begin{array}{c}-0.199 * * * \\
(0.158)\end{array}$ & $\begin{array}{c}-0.111^{* * *} \\
(0.197)\end{array}$ & $\begin{array}{c}-0.212^{* *} \\
(0.177)\end{array}$ & $\begin{array}{c}-0.352^{* * *} \\
(0.164)\end{array}$ & $\begin{array}{c}-0.262^{* * *} \\
(0.0499)\end{array}$ & $\begin{array}{c}-0.220^{* *} \\
(0.151)\end{array}$ \\
\hline CLOSET INDEXRES & $\begin{array}{c}0.0143 \\
(0.0376)\end{array}$ & $\begin{array}{c}0.046 \\
(0.458)\end{array}$ & $\begin{array}{c}0.097 \\
(0.461)\end{array}$ & $\begin{array}{c}0.071 \\
(0.437)\end{array}$ & $\begin{array}{c}0.081 \\
(0.459)\end{array}$ & $\begin{array}{c}0.0266 \\
(0.0337)\end{array}$ \\
\hline$P C_{t-1}$ & $\begin{array}{c}0.793 * * * \\
(0.125)\end{array}$ & $\begin{array}{c}0.847 * * * \\
(0.0408)\end{array}$ & $\begin{array}{l}0.903^{*} \\
(0.126)\end{array}$ & $\begin{array}{c}0.860 * * * \\
(0.0366)\end{array}$ & $\begin{array}{c}0.837 * * * \\
(0.0600)\end{array}$ & $\begin{array}{l}0.836^{* *} \\
(0.0477)\end{array}$ \\
\hline$C C_{t-1}$ & $\begin{array}{c}0.838 * * * \\
(0.0536)\end{array}$ & $\begin{array}{c}0.903 * * \\
(0.126)\end{array}$ & $\begin{array}{l}0.847 * * \\
(0.0415)\end{array}$ & $\begin{array}{c}0.865^{* * *} \\
(0.0505)\end{array}$ & $\begin{array}{c}0.841^{* * * *} \\
(0.0402)\end{array}$ & $\begin{array}{l}0.847 * * \\
(0.0432)\end{array}$ \\
\hline PROP & $\begin{array}{c}0.362 * * * \\
(11.160)\end{array}$ & $\begin{array}{c}0.430^{* * *} \\
(11.977)\end{array}$ & $\begin{array}{c}0.499 * * * \\
(12.780)\end{array}$ & $\begin{array}{c}1.079 * * * \\
(21.195)\end{array}$ & $\begin{array}{l}1.046^{* * *} \\
(19.599)\end{array}$ & $\begin{array}{l}1.043^{* * *} \\
(19.096)\end{array}$ \\
\hline LN_SALE & $\begin{array}{c}0.144 * * * \\
(27.733)\end{array}$ & $\begin{array}{c}0.141^{* * *} \\
(23.434)\end{array}$ & $\begin{array}{c}0.112 * * * \\
(16.428)\end{array}$ & $\begin{array}{c}0.184 * * * \\
(22.546)\end{array}$ & $\begin{array}{c}0.171^{* * *} \\
(19.148)\end{array}$ & $\begin{array}{c}0.121^{* * * *} \\
(12.636)\end{array}$ \\
\hline RDTA & $\begin{array}{c}-0.011 \\
(-0.232)\end{array}$ & $\begin{array}{c}-0.146 * * * \\
(-2.599)\end{array}$ & $\begin{array}{c}-0.225^{* * *} \\
(-3.536)\end{array}$ & $\begin{array}{c}-0.189 * * \\
(-2.549)\end{array}$ & $\begin{array}{c}-0.326^{* * *} \\
(-3.921)\end{array}$ & $\begin{array}{c}-0.415^{* * *} \\
(-4.687)\end{array}$ \\
\hline ROA & $\begin{array}{c}-0.227^{* * *} \\
(-9.927)\end{array}$ & $\begin{array}{c}-0.252 * * * \\
(-9.320)\end{array}$ & $\begin{array}{c}-0.256^{* * *} \\
(-8.389)\end{array}$ & $\begin{array}{c}-0.305^{* * *} \\
(-8.558)\end{array}$ & $\begin{array}{c}-0.333 * * * \\
(-8.321)\end{array}$ & $\begin{array}{c}-0.318^{* * *} \\
(-7.518)\end{array}$ \\
\hline PPETA & $\begin{array}{l}-0.068^{*} \\
(-1.787)\end{array}$ & $\begin{array}{c}-0.069 \\
(-1.630)\end{array}$ & $\begin{array}{c}-0.033 \\
(-0.696)\end{array}$ & $\begin{array}{c}-0.235 * * * \\
(-3.933)\end{array}$ & $\begin{array}{c}-0.214 * * * \\
(-3.397)\end{array}$ & $\begin{array}{c}-0.147^{* *} \\
(-2.205)\end{array}$ \\
\hline LEV & $\begin{array}{c}-0.059 * * * \\
(-3.070)\end{array}$ & $\begin{array}{c}0.035 \\
(1.583)\end{array}$ & $\begin{array}{c}0.060^{* *} \\
(2.471)\end{array}$ & $\begin{array}{c}0.024 \\
(0.816)\end{array}$ & $\begin{array}{c}0.152 * * * \\
(4.685)\end{array}$ & $\begin{array}{c}0.172^{* * * *} \\
(5.117)\end{array}$ \\
\hline CAPEXTA & $\begin{array}{c}-0.145^{* * *} \\
(-2.987)\end{array}$ & $\begin{array}{c}-0.250^{* * *} \\
(-4.429)\end{array}$ & $\begin{array}{c}-0.303 * * * \\
(-4.651)\end{array}$ & $\begin{array}{c}-0.254 * * * \\
(-3.345)\end{array}$ & $\begin{array}{c}-0.345^{* * *} \\
(-4.141)\end{array}$ & $\begin{array}{c}-0.386^{* * *} \\
(-4.247)\end{array}$ \\
\hline Q & $\begin{array}{c}-0.001 \\
(-0.413)\end{array}$ & $\begin{array}{c}-0.002 \\
(-1.245)\end{array}$ & $\begin{array}{c}-0.000 \\
(-0.142)\end{array}$ & $\begin{array}{c}-0.001 \\
(-0.405)\end{array}$ & $\begin{array}{c}-0.006^{* *} \\
(-2.128)\end{array}$ & $\begin{array}{c}-0.001 \\
(-0.306)\end{array}$ \\
\hline HHI & $\begin{array}{c}0.024 \\
(0.289)\end{array}$ & $\begin{array}{c}0.079 \\
(0.857)\end{array}$ & $\begin{array}{c}0.049 \\
(0.481)\end{array}$ & $\begin{array}{c}-0.323 * * \\
(-2.491)\end{array}$ & $\begin{array}{c}-0.211 \\
(-1.553)\end{array}$ & $\begin{array}{c}-0.216 \\
(-1.541)\end{array}$ \\
\hline HHI squared & $\begin{array}{c}0.058 \\
(0.692)\end{array}$ & $\begin{array}{c}0.011 \\
(0.118)\end{array}$ & $\begin{array}{c}0.025 \\
(0.250)\end{array}$ & $\begin{array}{c}0.372 * * * \\
(2.850)\end{array}$ & $\begin{array}{l}0.258^{*} \\
(1.892)\end{array}$ & $\begin{array}{l}0.241^{*} \\
(1.714)\end{array}$ \\
\hline LN_AGE & $\begin{array}{c}0.101 * * * \\
(7.033)\end{array}$ & $\begin{array}{c}0.175^{* * *} \\
(9.020)\end{array}$ & $\begin{array}{c}0.288^{* * *} \\
(11.234)\end{array}$ & $\begin{array}{c}-0.035 \\
(-1.547)\end{array}$ & $\begin{array}{c}0.077 * * * \\
(2.673)\end{array}$ & $\begin{array}{c}0.237 * * * \\
(6.625)\end{array}$ \\
\hline Year & YES & YES & YES & YES & YES & YES \\
\hline Industry & NO & NO & NO & NO & NO & NO \\
\hline No. of obs. & 48,289 & 40,905 & 34,538 & 48,289 & 40,905 & 34,538 \\
\hline Adj.R squared & 0.126 & 0.117 & 0.113 & 0.168 & 0.102 & 0.146 \\
\hline
\end{tabular}


This table reports the results of the firm-fixed effect regressions of the patent count (Panel A) and patent citations (Panel B). The dependent variables are PC, which is the natural logarithm of one plus number of patents filed and eventually granted (Panel A), and CC, which is the natural logarithm of one plus the number of non-self-citations. (Panel B). Institutional investors are classified into five groups based upon the classification of Petajisto (2013). STOCK PICKERS, CONCENTRATED, FACTOR BETS, MODERATELY ACTIVE and CLOSET INDEXERS are calculated as the average percentage of firm's i outstanding shares held by stock pickers, concentrated, factor bets, moderately active and closet indexers, respectively at the end of year $t$. The definitions of control variables are provided in Table $2 . *, * *$ and $* * *$ indicate statistical significance at the $10 \%, 5 \%$, and $1 \%$ level, respectively. 
Table 9 - Three-stage least squared regressions

\begin{tabular}{|c|c|c|c|c|}
\hline \multirow[b]{2}{*}{ Dependent Variable } & \multicolumn{2}{|c|}{ Panel A: Patent Count } & \multicolumn{2}{|c|}{ Panel B: Citation Count } \\
\hline & $P C_{t+3}$ & $I O V_{t+3}$ & $C C_{t+3}$ & $I O V_{t+3}$ \\
\hline \multirow[t]{2}{*}{ IOV } & $-3.417 * * *$ & - & $-7.631 * * *$ & - \\
\hline & $(-4.134)$ & - & $(-5.812)$ & - \\
\hline \multirow[t]{2}{*}{ PROP } & $1.391 * * *$ & - & $1.622 * * *$ & - \\
\hline & $(7.432)$ & - & $(6.732)$ & - \\
\hline \multirow[t]{2}{*}{$\mathrm{PC}$} & - & $0.408 * * *$ & - & - \\
\hline & - & $(16.442)$ & - & - \\
\hline \multirow[t]{2}{*}{$\mathrm{CC}$} & - & - & - & $0.544 * * *$ \\
\hline & - & - & - & $(17.539)$ \\
\hline \multirow[t]{2}{*}{ LN_SALE } & $1.231 * * *$ & $0.734 * * *$ & $1.815^{* * *}$ & $0.451 * * *$ \\
\hline & $(7.244)$ & $(16.812)$ & $(9.422)$ & $(14.192)$ \\
\hline \multirow[t]{2}{*}{ RDTA } & $3.592 * * *$ & - & $4.732 * * *$ & - \\
\hline & $(6.722)$ & - & $(7.377)$ & - \\
\hline \multirow[t]{2}{*}{ ROA } & $-1.731 * * *$ & - & $-1.317 * * *$ & - \\
\hline & $(-4.821)$ & - & $(-3.342)$ & - \\
\hline \multirow[t]{2}{*}{ PPETA } & $0.381 * * *$ & - & 0.001 & - \\
\hline & $(1.122)$ & - & $(0.021)$ & - \\
\hline \multirow[t]{2}{*}{ LEV } & -1.108 & - & -0.632 & - \\
\hline & $(-1.231)$ & - & $(-1.723)$ & - \\
\hline \multirow[t]{2}{*}{ CAPEXTA } & 0.538 & - & 0.734 & - \\
\hline & $(0.181)$ & - & $(0.084)$ & - \\
\hline \multirow[t]{2}{*}{ Q } & $0.022 * * *$ & - & $0.069 * * *$ & - \\
\hline & $(3.361)$ & - & $(4.738)$ & - \\
\hline \multirow[t]{2}{*}{ HHI } & -0.012 & - & -0.002 & - \\
\hline & $(-0.02)$ & - & $(-1.381)$ & - \\
\hline \multirow[t]{2}{*}{ HHI squared } & $1.991 * * *$ & - & $1.811 * *$ & - \\
\hline & $(6.491)$ & - & $(2.732)$ & - \\
\hline \multirow[t]{2}{*}{ LN_AGE } & $0.781 * * *$ & - & $0.942 * * *$ & - \\
\hline & $(6.917)$ & - & $(5.228)$ & - \\
\hline \multirow[t]{2}{*}{ LN_SHARES } & - & $-0.551 * * *$ & - & $0.439 * * *$ \\
\hline & - & $(-4.832)$ & - & $(-6.321)$ \\
\hline \multirow[t]{2}{*}{ TURNOVER } & - & $-0.033 * * *$ & - & $0.027 * * *$ \\
\hline & - & $(-2.562)$ & - & $(-3.183)$ \\
\hline Year & YES & YES & YES & YES \\
\hline
\end{tabular}




\begin{tabular}{lcccc} 
Industry & YES & YES & YES & YES \\
No. of obs. & 3,238 & 3,238 & 3,238 & 3,238 \\
Adj.R squared & 0.272 & 0.371 & 0.291 & 0.394 \\
\hline
\end{tabular}

This table reports the results from the 3SLS regressions of the patent count and patent citations. The definitions of variables are provided in Table 2. Additionally, LN_SHARES is the natural log of the number of shares outstanding of the firm. TURNOVER is the average of the daily ratio of trading volume to the total number of shares outstanding. *, ** and *** indicate statistical significance at the $10 \%, 5 \%$, and $1 \%$ level, respectively. 
Table 10 - Fixed-effect Regressions for change in institutional ownership proportion

\begin{tabular}{|c|c|c|c|c|}
\hline \multirow[b]{2}{*}{ Dependent Variable } & \multicolumn{2}{|c|}{ Panel A: Patent Count } & \multicolumn{2}{|c|}{ Panel B: Citation Count } \\
\hline & $\begin{array}{c}P C_{t+1} \\
(1)\end{array}$ & $\begin{array}{r}P C_{t+1} \\
(2)\end{array}$ & $\begin{array}{c}C C_{t+1} \\
(3) \\
\end{array}$ & $\begin{array}{c}C C_{t+1} \\
(4) \\
\end{array}$ \\
\hline$\triangle \mathrm{PROP}$ (POSITIVE) & $\begin{array}{c}0.576^{* * *} \\
(5.072)\end{array}$ & - & $\begin{array}{c}1.106^{* * *} \\
(6.222)\end{array}$ & - \\
\hline$\triangle \mathrm{PROP}$ (NEGATIVE) & $\begin{array}{l}- \\
-\end{array}$ & $\begin{array}{c}0.072 \\
(0.633)\end{array}$ & - & $\begin{array}{c}-0.069 \\
(-0.389)\end{array}$ \\
\hline LN_SALE & $\begin{array}{c}0.178 * * * \\
(25.933)\end{array}$ & $\begin{array}{c}0.134 * * * \\
(13.374)\end{array}$ & $\begin{array}{c}0.237 * * * \\
(21.992)\end{array}$ & $\begin{array}{c}0.197^{* * *} \\
(12.759)\end{array}$ \\
\hline RDTA & $\begin{array}{c}0.120 \\
(1.615)\end{array}$ & $\begin{array}{c}-0.101 \\
(-1.261)\end{array}$ & $\begin{array}{c}-0.190 \\
(-1.631)\end{array}$ & $\begin{array}{c}-0.114 \\
(-0.920)\end{array}$ \\
\hline ROA & $\begin{array}{c}-0.324 * * * \\
(-9.759)\end{array}$ & $\begin{array}{c}-0.210^{* * *} \\
(-4.975)\end{array}$ & $\begin{array}{c}-0.456 * * * \\
(-8.768)\end{array}$ & $\begin{array}{c}-0.282 * * * \\
(-4.330)\end{array}$ \\
\hline PPETA & $\begin{array}{l}-0.089^{*} \\
(-1.808)\end{array}$ & $\begin{array}{c}0.072 \\
(0.968)\end{array}$ & $\begin{array}{c}-0.276^{* * *} \\
(-3.600)\end{array}$ & $\begin{array}{c}-0.041 \\
(-0.352)\end{array}$ \\
\hline LEV & $\begin{array}{c}-0.079 * * * \\
(-2.923)\end{array}$ & $\begin{array}{c}-0.013 \\
(-0.390)\end{array}$ & $\begin{array}{c}0.041 \\
(0.984)\end{array}$ & $\begin{array}{c}0.006 \\
(0.124)\end{array}$ \\
\hline CAPEXTA & $\begin{array}{l}-0.114^{*} \\
(-1.768)\end{array}$ & $\begin{array}{c}-0.191 * * \\
(-2.031)\end{array}$ & $\begin{array}{c}-0.227 * * \\
(-2.256)\end{array}$ & $\begin{array}{c}-0.292 * * \\
(-2.012)\end{array}$ \\
\hline Q & $\begin{array}{c}-0.003 \\
(-1.432)\end{array}$ & $\begin{array}{c}0.002 \\
(0.655)\end{array}$ & $\begin{array}{l}-0.006^{*} \\
(-1.854)\end{array}$ & $\begin{array}{c}0.004 \\
(1.019)\end{array}$ \\
\hline HHI & $\begin{array}{c}-0.068 \\
(-0.642)\end{array}$ & $\begin{array}{c}0.352^{* *} \\
(2.168)\end{array}$ & $\begin{array}{c}-0.435^{* * *} \\
(-2.635)\end{array}$ & $\begin{array}{c}0.040 \\
(0.161)\end{array}$ \\
\hline HHI squared & $\begin{array}{c}0.163 \\
(1.533)\end{array}$ & $\begin{array}{c}-0.230 \\
(-1.418)\end{array}$ & $\begin{array}{c}0.481 * * * \\
(2.896)\end{array}$ & $\begin{array}{c}0.090 \\
(0.358)\end{array}$ \\
\hline LN_AGE & $\begin{array}{c}0.130^{* * *} \\
(6.801)\end{array}$ & $\begin{array}{c}-0.039 \\
(-1.461)\end{array}$ & $\begin{array}{c}-0.046 \\
(-1.530)\end{array}$ & $\begin{array}{c}-0.224 * * * \\
(-5.392)\end{array}$ \\
\hline Year & YES & YES & YES & YES \\
\hline Industry & NO & NO & NO & NO \\
\hline No. of obs. & 33,365 & 14,701 & 33,365 & 14,701 \\
\hline Adj.R squared & 0.171 & 0.672 & 0.147 & 0.542 \\
\hline
\end{tabular}

This table reports the results of the firm-fixed effect regressions of the patent count (Panel A) and patent citations (Panel B). The dependent variables are PC, which is the natural logarithm of one plus number of patents filed and eventually granted (Panel A), and CC, which is the natural logarithm of one plus the number of non-self-citations. (Panel B). The definitions of control variables are provided in Table 2. * ** and *** indicate statistical significance at the $10 \%, 5 \%$, and $1 \%$ level, respectively. 